University of Texas Rio Grande Valley

ScholarWorks @ UTRGV

Anthropology Faculty Publications and

Presentations

College of Liberal Arts

4-2-2019

\title{
'Doing' Llama Face Stew: A Late Moche Culinary Assemblage as a Domestic Dedicatory Deposit
}

Guy S. Duke

University of Texas Rio Grande Valley, guy.duke@utrgv.edu

Follow this and additional works at: https://scholarworks.utrgv.edu/anthro_fac

Part of the Anthropology Commons

\section{Recommended Citation}

Duke, G. S. (2019). 'Doing' Llama Face Stew: A Late Moche Culinary Assemblage as a Domestic Dedicatory Deposit. Cambridge Archaeological Journal 29(3), 517-535. https://doi.org/10.1017/ S0959774319000179

This Article is brought to you for free and open access by the College of Liberal Arts at ScholarWorks @ UTRGV. It has been accepted for inclusion in Anthropology Faculty Publications and Presentations by an authorized administrator of ScholarWorks @ UTRGV. For more information, please contact justin.white@utrgv.edu, william.flores01@utrgv.edu. 


\title{
'Doing' Llama Face Stew: A Late Moche Culinary Assemblage as a Domestic Dedicatory Deposit
}

\author{
Guy S. Duke
}

\begin{abstract}
Presented here is a meal from a simple cooking vessel, excavated from the Late Moche ( $A D$ 600-850) site of Wasi Huachuma on the north coast of Peru. This meal, cooked in a whole, plain vessel and spilled beneath the floor of a domestic structure, was unambiguously marked by a large stone embedded in the floor. It contained diverse plant and animal materials associated with the sea, the coastal plains, the highlands and the jungle. Via its contents and placement, this meal embodies the ways in which the domestic world of exchange and interaction was deeply entangled with the spiritual and political. All at once, this meal was utilitarian, domestic, industrial, ritually charged and politically embedded. Within it, the fruits of communities, geographical regions and ideas were assembled together to be realized as a dedicatory offering within, and potentially to, this domestic structure. I argue that this meal both contains and is contained by a milieu that is eminently local and mundane as well as worldly and supernatural.
\end{abstract}

This story starts with a meal. A meal cooked at the Late Moche (AD 600-850) site of Wasi Huachuma, located on the north side of the lower Jequetepeque river on the north coast of Peru. It was cooked within a plain, utilitarian pot with a standard form, ubiquitous amongst cooking vessels across multiple time periods in this region. It was prepared in a typical, quotidian style-boiling-contained typical, quotidian materials in a typical, quotidian pot. And yet this was far more than a simple meal. This meal, in this pot, brought together a local, yet interregional cuisine: a cuisine that featured products from the sea, the irrigated coastal plain, the highlands and the jungle. It included dietary staples as well as both flavourful condiments and important ritual or medicinal ingredients. Animals were combined with plants and boiled together in water, assembled into an inseparable stew. However, this meal was not consumed by its makers.

The meal and the unadorned, utilitarian cooking pot in which it was cooked were buried under the floor of a structure and covered with a large, prominent stone that marked its presence. It was a meal that was created and intentionally deposited by its makers immediately prior to the construction of a domestic structure. The dedicatory deposit of this meal before the construction of this structure occurred during the particularly tumultuous Late Moche period on the north coast of Peru (Castillo 2001; Dillehay 2001; Quilter \& Koons 2012; Swenson 2007). According to Swenson and Warner $(2016,46)$, the defining characteristic of the region during this period was the florescence of multiple feasting centres, a proliferation directly associated with political decentralization and the rise of new forms of ritual observance (see also Swenson 2006; 2008). Indeed, the emergence of numerous smaller centres on the north side of the Jequetepeque river occurred concurrent with a general shift from the south to the north (Dillehay \& Kolata 2004; Donnan 2007; Moseley et al. 2008; Swenson 2004; Swenson \& Warner 2016) with evidence from Cerro Chepén (Rosas Rintel 2010), San Ildefonso (Swenson 2008), Portachuelo de Charcape (Johnson 2011) and Wasi Huachuma (Duke 2017), amongst other sites (Swenson 2004) exemplifying this shift. It is within this unstable context that a new domestic structure was erected and this meal was deliberately placed beneath it. 


\section{Ritual, 'doings', consumption and contextuality}

Food, whether used in an economic or ritual context, can signify spheres of ideological, economic and technological practices on multiple scales and should be understood for its social importance. The entangled convergences of food, ritual, cooking style and daily activities show us how deeply nondaily, special events inform everyday practice, but also that this quotidian, utilitarian world underwrites these special events in both literal and figurative ways. It is through the assemblage of specific materials in specific contexts that social meaning is encapsulated and created (DeLanda 2006; Deleuze \& Guattari 1993). However, it is the act of assembly itself that imbues the materials with those social meanings.

As Amanda Logan $(2012,6)$ has asserted: 'as a starting point, foodways must be studied as actions or practices, how people 'do things,' not just species lists.' The practices, actions, and rituals performed in the preparation and consumption of food are the ultimate purpose of study, whether the focus is grand feasts, simple meals, or something in between. Severin Fowles (2013) applies the term 'doings' as a means of better understanding past practices, specifically defining them 'as practices characterized by a heightened awareness of interconnectedness and the relations between things' (Fowles 2013, 103). While Fowles applies 'doings' as a translation of a Puebloan word used to describe activities that most anthropologists might consider 'ritual', in the context of a dedicatory deposit of a utilitarian pot containing the detritus of a meal, the concept of 'doing' is particularly salient. Indeed, the interconnectivity between the preparation/consumption of food and religious/ritual practice is a crucial component of understanding the world of the Moche. The consumption of food at specific and often powerful places, whether as part of conspicuous feasting events or small meals shared with kin while in temporary camps during pilgrimages, brought people together and united them with a specific place and shared identity. In fact, Swenson and Warner (2016) have postulated for the Late Moche ceremonial site of Huaca Colorada that the consumption of food was not only intimately tied to place, but the place itself was a consumer and in need of nourishment via a variety of sacrificial offerings.

Michael Dietler (2001) acknowledges the entanglements between power and ritual. To Dietler (2001, 67), a ritual act can be an elaborate, public spectacle, with attendant conspicuous consumption in the form of feasts taking place on or near monumental architecture, or a simple, individual act with little material trace. Additionally, he specifically points out that ritual also need not be sacred or religious. Instead, Dietler, following Kertzer (1988, 9), identifies 'the defining criterion of rituals is that they are in some way symbolically differentiated from everyday activities in terms of forms of action or purpose (Dietler 2001, 67). In essence, the argument made by Dietler $(2001,70)$ is that ritual acts are performative, with feasting as publicly performed ritual defined against the private, almost anonymous performance of everyday domestic ritual.

However, the separation of the domestic and ritual spheres is a problematic divide. Joanna Brück (1999) has critiqued the ritual/domestic dichotomy as being a projection of contemporary distinctions onto past practices that has severely limited our abilities to understand them. In essence, she argues that these past practices all followed an internal and entirely practical logic which not only blurred the distinction between quotidian and ritual, but merged them into one and the same, effectively eliminating the discrete, catch-all category of 'ritual' altogether. To Brück, all practices are symbolic, and all symbols are practical.

Severin Fowles $(2013,7)$ asks, 'What is ritual? What is it not? When is a building a temple rather than an elite residence? How is one to pull from the entangled categories of premodernity some strands of behavior that can serve as the special subject matter of an archaeology of religion?' While Brück (1999) rejects 'ritual' for being a catch-all term for supposedly irrational behaviours, arguing instead that all behaviour is rational and logical to the practitioner, Fowles (2013) rejects 'religion' for being a construct of post-Reformation European modernism created as a categorical contrast to the similarly created discrete realms of 'politics' and 'economics'. Both positions arise from similar dissatisfactions with the ways in which the supposedly non-economic and non-political realms are addressed in the anthropological and archaeological literature. The key difference between them, as noted by Fowles $(2013,10)$, is that where Brück seeks alternative perspectives of the world, Fowles, following Alberti and colleagues (Alberti \& Bray 2009; Alberti \& Marshall 2009; Alberti et al. 2011), seeks alternative worlds altogether. His rejection of 'religion' calls not for attempts to rationalize and make legible in our own world the practices of the past, but to attempt to understand the non-modern worlds of the past (and present) on their own terms.

'Doings' are practices rooted in specific historical contexts, performed by people, and are 
inextricable from, but not defined by, the materials through which they are enacted. These doings are not instinctual or natural. As people operating in the world, we actively adapt and adjust our interactions to the contexts in which we find ourselves. These interactions are bodily performed with material objects and immaterial concepts, all of which are inextricably intertwined. The crucial element here is the act of doing, an act that must be learned within a social context. In essence, the exploration of the practices of cooking and eating of specific foods by specific people at specific times and places requires the basic understanding that these practices are taught and learned by individual members of particular groups who maintain these practices while also modifying them in personal ways. To quote Marcel Mauss $(1973,71)$, 'a manual knack can only be learnt slowly'. While the recovery of recipes, complete with instructions and serving suggestions, is not generally possible, the rich and varied archaeological evidence of food preparation and consumption provides an excellent arena for exploring the continuities and dislocations between different types of culinary practices.

\section{Moche culinary traditions in and out of context}

Food and drink are generally considered under the same umbrella. Both are ingested, require preparation and have significant social meanings connected to them. In the Andes, both are frequently discussed in regard to the reciprocal feasting economies prevalent in the region over the millennia (e.g. Bray 2003; Chicoine 2011; Gumerman 2010; Hastorf 2003; Isbell \& Groleau 2010; Knudson et al. 2012; Lau 2002; Logan et al. 2012; Nash 2010; Swenson 2006). However, drink, and in particular the various forms of the mildly alcoholic beverage chicha, have taken precedence, with food taking a secondary or even tertiary role behind chicha and a variety of psychoactive substances in discussions of the social importance of ingested substances (e.g. Bussmann \& Sharon 2009; Cummins 2002; de Rios 1977; Glowacki 2005; Hayashida 2008; Jennings \& Bowser 2009; Martin 1970; Morris 1979). More commonly, food has been considered for its dietary and nutritional significance, rather than its symbolic importance (e.g. Gagnon 2004; Kellner \& Schoeninger 2007; Kurin 2015; Pozorski 1979; Quilter \& Stocker 1983; Quilter et al. 1991). This is not to say that the symbolism of food in the Andes has been ignored (e.g. Cutright 2011; Hastorf 1991; Ryser 2008). Instead, what I seek here, in part, is to show that everyday foods were equally as ritually important as alcoholic beverages and other perception-altering substances.

For the most part, preconquest Andean cooking was rooted in two primary techniques: boiling and roasting (Bray 2003, 8; Rowe 1946, 220-21). The stews, gruels, pottages and soups that dominated the culinary repertoire contained a varied combination of comestibles. Evidence from multiple sites in the lower Jequetepeque Valley shows a mixed dietary emphasis including agricultural produce from the nearby irrigated fields, as well as marine resources and domesticated terrestrial fauna (see Chiou 2017; Duke 2017; Johnson 2011, 58-9; Rosas R. 2010, 74173; Swenson 2004, appendix B). Shellfish, camelids and maize, along with guinea pig, local fish, squash and crab were all in use during the Late Moche period. While cooking techniques appeared relatively consistent across time, within the Moche region and especially in the Jequetepeque Valley during the Late Moche period there is evidence for transformations in culinary practices connected to a likely combination of factors, including shifts in political organization and environmental change.

The earliest evidence of Moche material culture in the Jequetepeque valley comes from the sites of La Mina, Masanca and Dos Cabezas, first occupied around $\mathrm{AD} 300$ and continuing until around $\mathrm{AD} 850$ (Dillehay \& Kolata 2004; Donnan 2006; 2007; Johnson \& Zori 2011; Narváez 1994; Swenson 2004; Swenson \& Warner 2016). While the occupation of Dos Cabezas spanned both the Early and Middle Moche periods in the Jequetepeque, the Middle Moche period saw increased expansion of irrigation, particularly on the north side of the river (Castillo 2010), a possible response to an increase in the availability of water in general due to the end of a long drought preceding this era. In fact, the two largest sites from the Middle Moche period in the Jequetepeque were both on the north side of the river: Pacatnamú and San José de Moro (Johnson \& Zori 2011, 10).

The Moche occupation at Pacatnamú was most intensive in the Middle Moche period, but continued into the Late Moche and well beyond, into the Lambayeque era (Donnan 1997; Donnan \& Cock 1997). The site is marked by a number of large adobe pyramids, expansive residential areas, numerous plazas and extensive, well-preserved burials, both elite and commoner (Donnan \& McClelland 1979; Zori 2011). Situated at the mouth of the Jequetepeque, atop the ridge directly above the river and overlooking the abandoned site of Dos Cabezas, Pacatnamú was a strategic and symbolically important urban and mortuary centre (Donnan 
1997; Gumerman 1994). Occupying a place with vistas extending up the valley and along the coast, Pacatnamú was an important nexus point in coastal and inter-valley trade as well as a place of significant symbolic import, in part due to its proximity to Dos Cabezas and the Pacific Ocean (Donnan 1997).

Large amounts of well-preserved botanical remains were found within the Moche burial components excavated at Pacatnamú (Gumerman 1994; 1997). Gumerman (1994, 401-2; 1997, 243) found that food offerings were present in nearly half of the burials excavated, and those lacking food remains had been disturbed or were poorly preserved. Seventeen species of plant were identified in the burials, with three of these (maize (Zea mays), bottle gourd (Lagenaria sicerania) and seaweed) occurring regularly (Gumerman 1997, 243). Other, less frequently recovered, but still common, plant materials included common bean (Phaseolus vulgaris), lima bean (Phaseolus lunatus), coca (Erythroxylum coca), peanut (Arachis hypogea), squash (Cucurbita sp.), cotton (Gossypium barbadense), pacay (Inga feuillei), lúcuma (Pouteria lucuma), espingo (Nectandra sp.), chili pepper (Caspicum sp.), acacia (Acacia sp.) and algarroba (Prosopis sp.) (Gumerman 1997, 245). Notably, Gumerman shows that maize was not only the most frequent plant offering in the burials, but that the offerings of maize were of a different type (14 -to 16-row varieties) than the maize excavated from Moche middens (8- to 10-row varieties) at Pacatnamú (Gumerman 1997, 243-5). Beyond the differences in types of maize, Gumerman (1994; 1997) points out that while there were minimal amounts of marine fauna present in Pacatnamú burials (fish bones and scales, unmodified shell and a single sea-mammal bone), the overwhelming predominance of agricultural goods in the burials is the opposite of what was excavated from Moche middens at Pacatnamú, in which marine resources (shellfish, fish and marine mammals) far outnumbered agricultural products. Llama (Lama glama), ${ }^{1}$ $\operatorname{dog}$ (Canis familiaris) and guinea pig (Cavia porcellus) have also been recorded in Moche burials at Pacatnamú (Donnan 1997, 34; Goepfert 2012, 106). The more varied diet of marine and agricultural resources indicated by the midden deposits ${ }^{2}$ when compared to the burial offerings is asserted by Gumerman to indicate that the dead were thought to need different foods from the living in the Moche period at Pacatnamú. However, as Goepfert (2012) highlights, burial offerings should not automatically be assumed as food offerings-sacrificial offerings had multiple meanings to Moche and these materials, particularly llama, could have had significance beyond consumption (see also Swenson 2011; 2012).

San José de Moro, located inland and east of the Catalina hills from Pacatnamú on the north side of the Jequetepeque river, was an important ceremonial site during both the Middle and Late Moche periods and during the Lambayeque era (Castillo 2010; 2012). Excavations here have focused on the extensive mortuary remains, partly due to the destruction of large portions of the residential areas from modern agricultural activity (Johnson \& Zori 2011, 11). However, the evidence demonstrates that the production of large amounts of chicha was undertaken, indicating that the site was a locus of feasts and redistributive exchanges. The general lack of botanical remains recovered from San José de Moro has been ascribed to poor preservation conditions due to the deleterious effects of frequent ENSO events and the subsequent changes in humidity and temperature at the site (Delibes \& Barrgán 2008, 106).

The emergence of numerous smaller centres on the north side of the river occurred concurrent with the general shift from the south to the north (Dillehay \& Kolata 2004; Donnan 2007; Moseley et al. 2008; Swenson 2004; Swenson \& Warner 2016). Evidence from Cerro Chepén (Rosas R. 2010), San Ildefonso (Swenson 2008) and Portachuelo de Charcape (Johnson 2011), and many other sites (see Swenson 2004), indicates that political instability was prevalent and that the 'popularization of Moche cultic practices' (Swenson \& Warner 2016, 46) was intimately connected to this. Evidence from these sites shows a continued mixed dietary emphasis including agricultural produce from the nearby irrigated fields, as well as marine resources and domesticated terrestrial fauna (see Johnson 2011, 58-9; Rosas R. 2010, 741-73; Swenson 2004, appendix B). Shellfish, camelids and maize, along with guinea pig, local fish, cotton, squash and crab were all in use at these sites in the Late Moche period. These materials were also represented at the Late Moche sites of Wasi Huachuma and Huaca Colorada.

For the Moche, food and food items were much more than simply a means of meeting dietary requirements. The vast array of food items depicted in ceramic form along with recurring themes in Moche iconography, such as the presentation of anthropomorphic bowls of food to a seated lord, exemplify the high value placed on comestibles (Donnan 1978, 66). Moreover, numerous depictions of hunting (Donnan 1978, 178-82) and fishing (Donnan 1978, 102-6), the presence of food and serving vessels in scenes of craft production (Donnan 1978 , 65), as well as the presence of food offerings 
in burials, highlight the extraordinary emphasis placed on the ideological importance of food in Moche society (Gumerman 1997).

Literature addressing the food and diet of the Moche has primarily focused on feasting, nutrition, economics, or ritual aspects of consumption. Without doubt, the ritual consumption of food by way of feasting was an integral part of Andean political, economic and religious life (Arsenault 1992; Bray 2003; Costin \& Earle 1989; Gumerman 1997; 2010; Hastorf 2003; Jennings \& Duke 2018; Swenson 2006). However, too often interpretations of past Andean practices are presumed, based on ethnographic and ethnohistoric observations, essentially fitting archaeological data to these observations rather than analysing them within their own particular contexts. There is, obviously, utility to interpreting the archaeological past based on more recent observations, but just as obviously there are serious limitations.

In Andean studies, the fingerprints of the Inka empire are noted everywhere. Yet powerful and farreaching though the Inka empire was in the Andes, it did not conquer the past (though one might argue they tried: see Bray 2009). Despite its undisputed influence on Andean societies across a massive geographical spread, the Inka empire was brief in its temporality and was truly an outlier in its organization when compared to the societies it succeeded. While the Inka built upon the traditions of societies such as Tiwanaku and Wari, incorporating aspects of mythology, engineering, political organization and statecraft into their own practices (Moore 2018), the Inka were pioneers in economic collection and redistribution, colonization and relocation, and expansion and domination.

As such, Moche practices need to be understood on their own terms. Unlike for the Inka, the organization of labour was not centralized, nor was the collection of foodstuffs or crafts. Instead, late Moche culinary politics were locally negotiated without the intervention, at any level, of state apparatuses. Domestic ritual performances were just as variable as feasts and the two types of meals were intimately interconnected with one another (Gumerman 2010; also see Graff \& Rodríguez-Alegría 2012; Klarich 2010, for some archaeological examples from elsewhere).

That households are more than structures where people undertake domestic economic activities, but locales of important daily and non-daily rituals, is no longer a controversial statement. Numerous ethnographic works, both in the Andean region and elsewhere, document the symbolic practices associated with the construction and subsequent occupation of domestic structures (e.g. Arnold 1992; Bourdieu 1979; Gose 1991; Mayer 1977; Weismantel 1989). Understanding that the production and consumption of food was a central element to household life, and that much of this ritual behaviour will revolve around these activities, is clear. It is with this in mind that I analyse the commensal politics and everyday foodways of the Late Moche period in the Jequetepeque Valley.

\section{The context}

The north coast of Peru has long been known as a focal point of interaction and convergence in the Andean region. With wide-ranging and longstanding connections with the nearby and more distant highlands and the eastern jungles, as well as the coasts to the north and south prominent in the archaeological record, researchers have regularly noted the inter- and intra-regional exchange of goods and ideas (Bawden 1996; Castillo 2012; Donnan 1992; Pozorski \& Pozorski 1979; Shimada 1982; Swenson 2004). The Moche period in the Jequetepeque Valley, which spanned from approximately AD 200 to 850, saw the expansion of irrigation systems and urbanization as well as a number of practices and traditions, from ceramic styles to modes of architectural construction. While these practices and traditions obviously were altered and modified over the centuries, it is clear that a definitive 'Moche tradition' was in evidence throughout the north coast valleys, including the Jequetepeque. By the Late Moche period ( $\mathrm{AD} 600-$ 850), political control of the Jequetepeque had splintered, with evidence pointing to a combination of environmental instability and political or military disruption from external groups leading to a period of internecine conflict (Castillo 2001; Dillehay 2001; Dillehay et al. 2004; Johnson 2011; Quilter \& Koons 2012; Shimada et al. 1991; Swenson 2007; 2008).

The Late Moche site of Wasi Huachuma is located on the lower northeast slope of the Catalina Hills, $12 \mathrm{~km}$ south of San José de Moro, $10 \mathrm{~km}$ northeast of Pacatnamu and $12 \mathrm{~km}$ west of Cerro Chepén, three major centres of political power during the Moche period in the Jequetepeque Valley (Castillo 2012; Cusicanqui M. 2010; Donnan \& Cock 1997; Rosas R. 2010) (Fig. 1). The site consists of seven distinct sectors delineated by three dry arroyos running northeast from the top of the hills to the irrigated plain below (Dillehay et al. 2009, 86-9; Duke 2017, 100-109; Swenson 2004, 609-17) (Fig. 2). I focus on a specific deposit found within Sector $C$, which is located on a ridge above and to the west of the ceremonial core of the site (Sector B) and is bordered on 


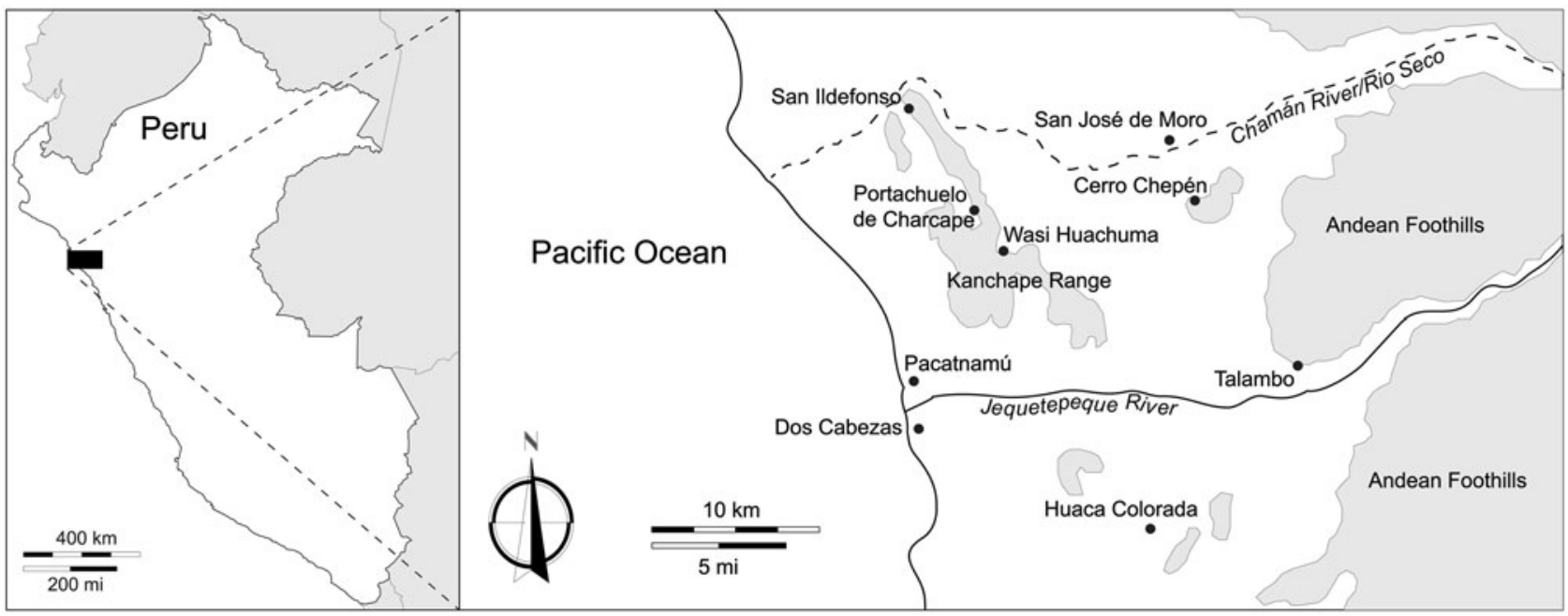

Figure 1. Map of the lower Jequetepeque Valley with important Moche sites.

its west by Arroyo 2. This sector features a number of stone alignments and disinterred burials, and in previous surveys had been identified as the primary residential sector (Dillehay et al. 2009, 86-9; Swenson 2004, 609-17). There is significant evidence of habitation and food processing, including burnt floors, hearths, food-processing implements, such as grinding stones, cutters and scrapers, and ceramic graters, and the remains of food items themselves (Duke 2017, 130-61).

Sector $C$ was the most complex sector at Wasi Huachuma, containing numerous structures, terraces and stone alignments as well as a small cemetery. It is likely that this area was used for a combination of residential, storage and domestic production activities. Sector C, particularly the northeast portion, was likely more intensively occupied, as indicated by the number of hearths excavated in the various units, as well as the greater concentrations of botanical and faunal materials (Duke 2017, 136-46). The foods (including maize, beans, chilli peppers, potato (Solanum tuberosum), squash, marine fish, guinea pig and camelid) prepared here were likely intended for the direct consumption of the inhabitants of this area.

The deposit in question was recovered from Unit 5-2013 in a sand matrix (Level 5) below the clay floor (Level 3) and sub-floor fill (Level 4) of a probable domestic structure on the northeast section of the Sector C residential zone (Fig. 3). The structure itself was not excavated in its entirety, but was defined as a domestic structure by a clay floor, a post-hole and a concentration of utilitarian ceramics and food detritus (Fig. 4). This likely domestic structure was identified on the surface by a long, stone alignment (Fig. 5). This was one of a number of stone alignments in this portion of the site (see Fig. 2 inset), and two nearby parallel walls were also excavated in the 2013 field season (Unit 9). Both units uncovered floors, hearths and food remains indicative of residential occupation.

The structure floor (Level 3) and the gravelly sand fill above it (Level 2) extended below an alignment of stones visible on the surface (designated Wall A within the unit), indicating that this stone alignment was added after the structure had been abandoned and subsequently buried (Fig. 6). A posthole and a large stone embedded in the floor were exposed as part of Level 3. The large stone penetrated the floor and sub-floor fill levels (Levels 4 and 5) and was positioned directly above a whole tinaja (Fig. 7). The vessel itself was found on its side within the sand matrix, with the mouth opening to the east and a splash zone of botanical and faunal materials surrounding it (Fig. 8).

A radiocarbon date was secured from the charred plant materials surrounding the whole vessel, giving a date of $1340 \pm 25$ вр or $1284-1179$ cal. вр (AD 666-771), placing it firmly within the Late Moche period.

\section{Assembling the llama face stew}

The composition of this deposit demands deeper scrutiny. First, the seemingly direct relationship between the two fill levels, the whole vessel and its contents, the floor and the stone embedded in the floor indicate that these were all intimately interconnected and were likely part of the same construction 


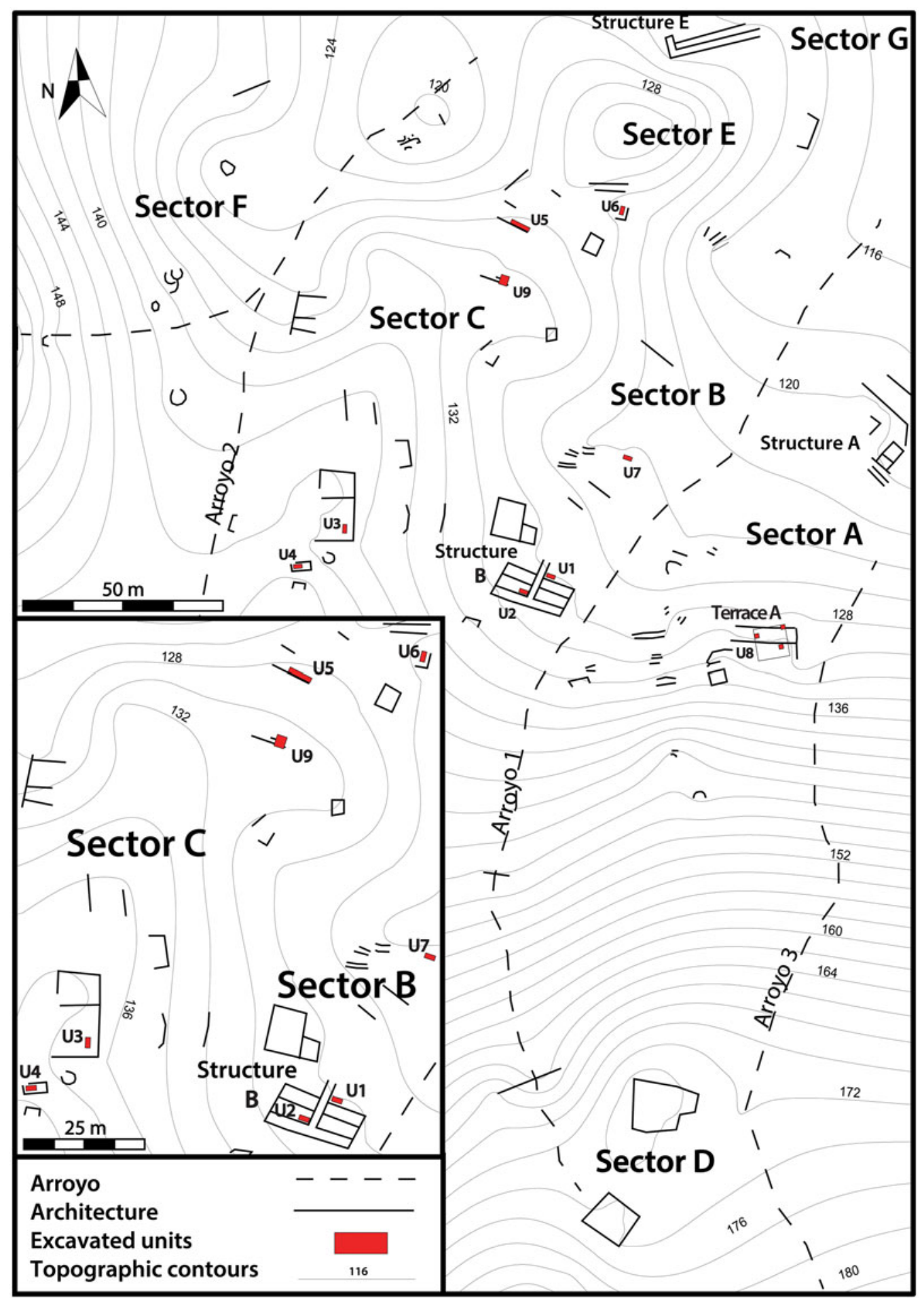

Figure 2. Topographic map of Wasi Huachuma and its designated sectors, with Sectors B $\mathcal{E} C$ inset.

event for the floor and that the pot and its contents were intentionally placed there prior to construction.

The pot itself is a standard cooking pot (Fig. 9). It has a wide mouth $(28 \mathrm{~cm})$ and a rounded bottom and measures $44 \mathrm{~cm}$ tall and $36 \mathrm{~cm}$ wide. It has an inverted aperture and gradually widens towards the middle, with a bulge in the lower half and relatively quick tapering to its rounded bottom. There 


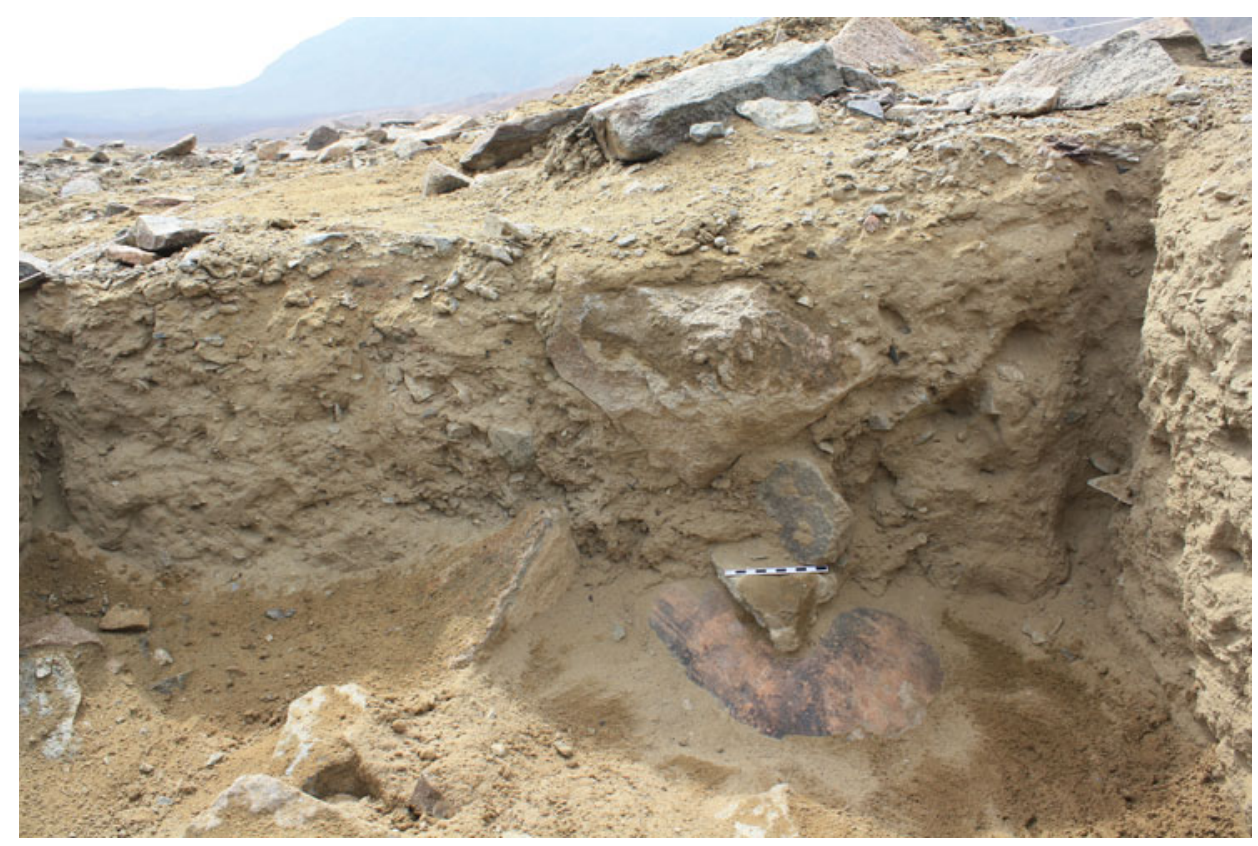

Figure 3. Whole vessel in context below large stone in Unit 5-2013, at Wasi Huachuma.

is evidence of exterior burning around the entire pot and interior burning on the bottom. While whole, it has cracks on the bottom and a notable, circular worn patch that appears to be an intentional modification, potentially as a level area to balance on. All of this indicates that this vessel was well used before being deposited. This style of pot has been noted throughout the northern Moche region (Johnson 2010, 506; Rosas R. 2010, 912; Swenson 2004, 746). It was used for boiling foods such as stews and in the making of chicha (maize beer), both at large and small scales. Its use spanned time periods from the Late Moche (AD 600-850) into the Late Intermediate Period (AD 1000-1400), possibly seven centuries of use.
Within the pot and its splash zone were the remains of the meal itself (Table 1). This varied assemblage of material included bones from domesticated animals such as guinea pig and the left maxilla of a two-year-old camelid (Lama sp.- - the llama face that is the namesake of this paper). Both were likely locally raised (see Shimada \& Shimada 1985), despite their initial domestication in the highlands centuries previously (Sandefur 1988, 155-7; Stahl 2008, 128).

This assemblage also contained locally produced agricultural products such as maize, common beans, squash, potato and chilli pepper. Additionally, coca, the only item not of local origin (Rosas R. 2010, 735), was also a part of this collection of materials.

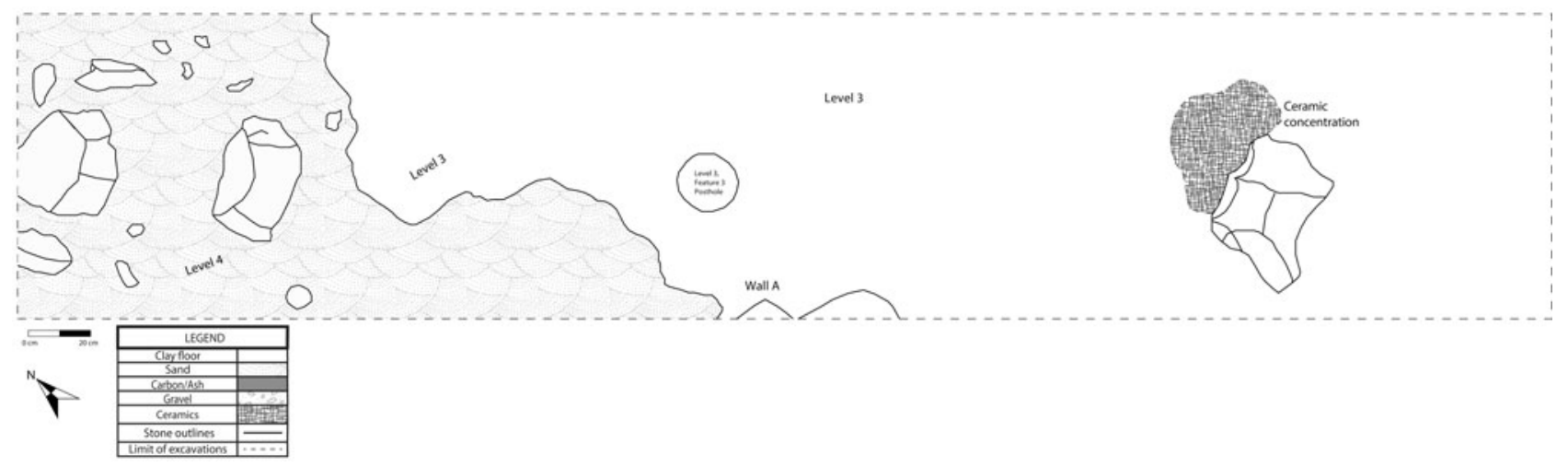

Figure 4. Plan map of Unit 5-2013, Level 3, with post-hole, stone and ceramic concentration identified. 


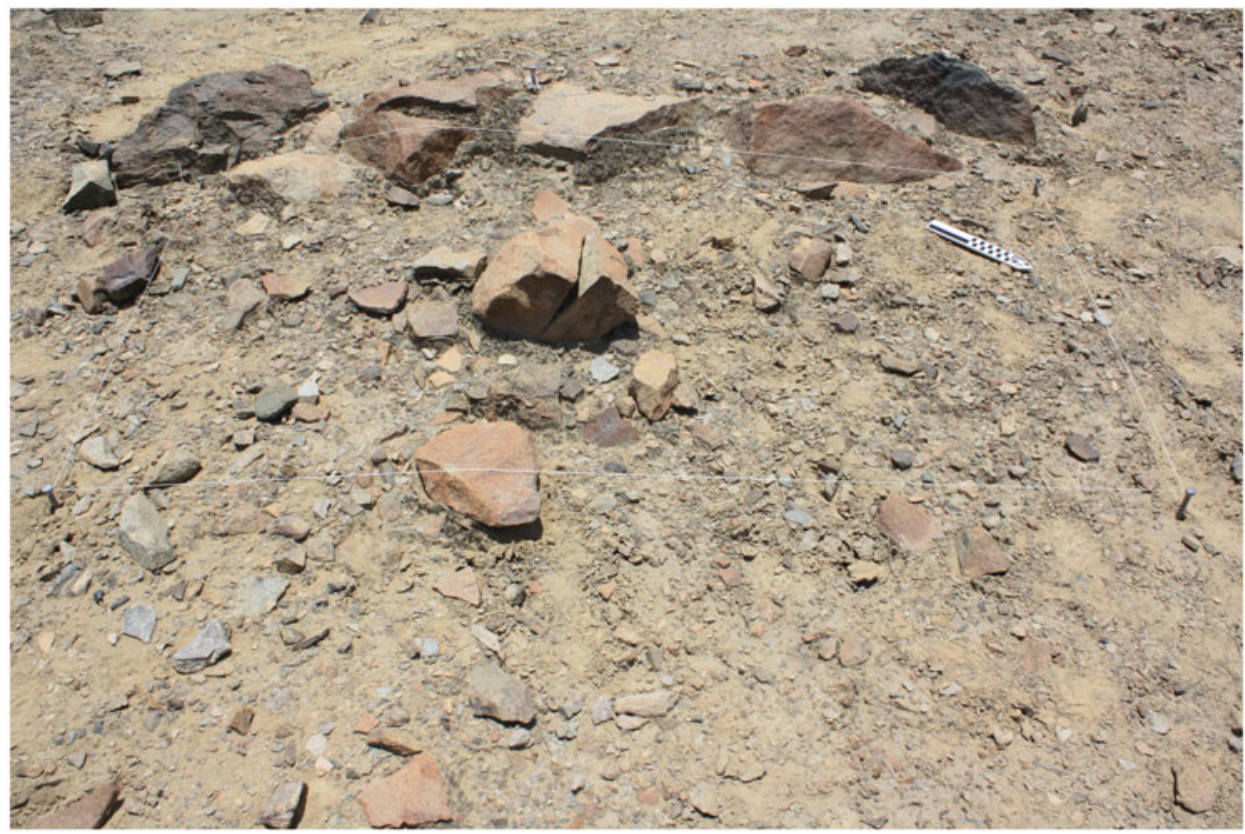

Figure 5. Surface stone alignment marking the structure associated with Unit 5-2013 at Wasi Huachuma.

Non-agricultural plants recovered from this assemblage were algarroba seeds and bark fragments from caper bushes (Capparis sp.).

Other locally sourced ingredients recovered from this deposit were freshwater crabs (Hypolobocera sp.), which may have been harvested from the river or local irrigation canals. Additionally, marine products such as fish (flathead mullet Mugil cephalus and sea snail Tegula atra) were included in this assemblage. These marine species would have been obtained from the nearby Pacific Ocean and brought to the site.

Aside from the plant and animal remains, a variety of ceramic fragments were found within and surrounding the larger, whole vessel, including sherds from a highly burnt vessel. Additionally, a lithic scraping tool was recovered from this assemblage.

In summary, this deposit of a whole ceramic vessel and a wide variety of food and food-related materials was recovered from a fill of clean sand beneath a large stone embedded in a clay floor of a residential structure. This residential structure was part of a complex of similar structures located in the northeast section of the likely residential portion of Wasi Huachuma (Sector C). These structures each featured floors, hearths and post-holes, as well as similar (if not identical) palaeobotanical and zooarchaeological remains (see Duke 2017, 137-46; Vásquez \& Rosales 2014), and clearly operated as the physical bases of

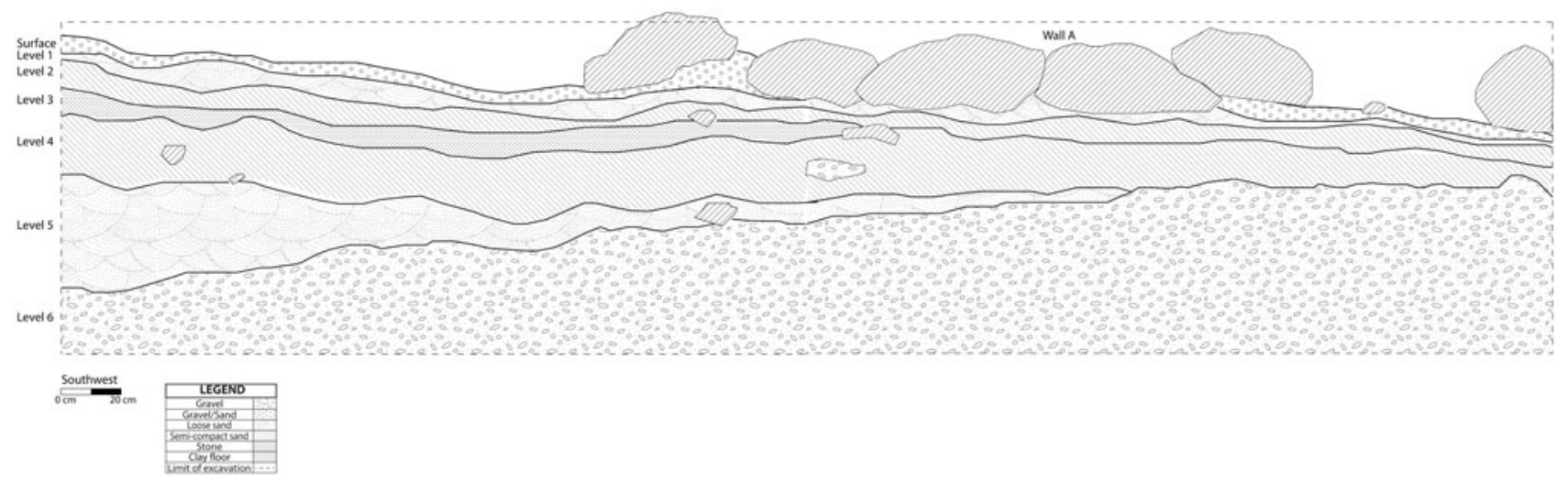

Figure 6. Unit 5-2013 southwest profile. 


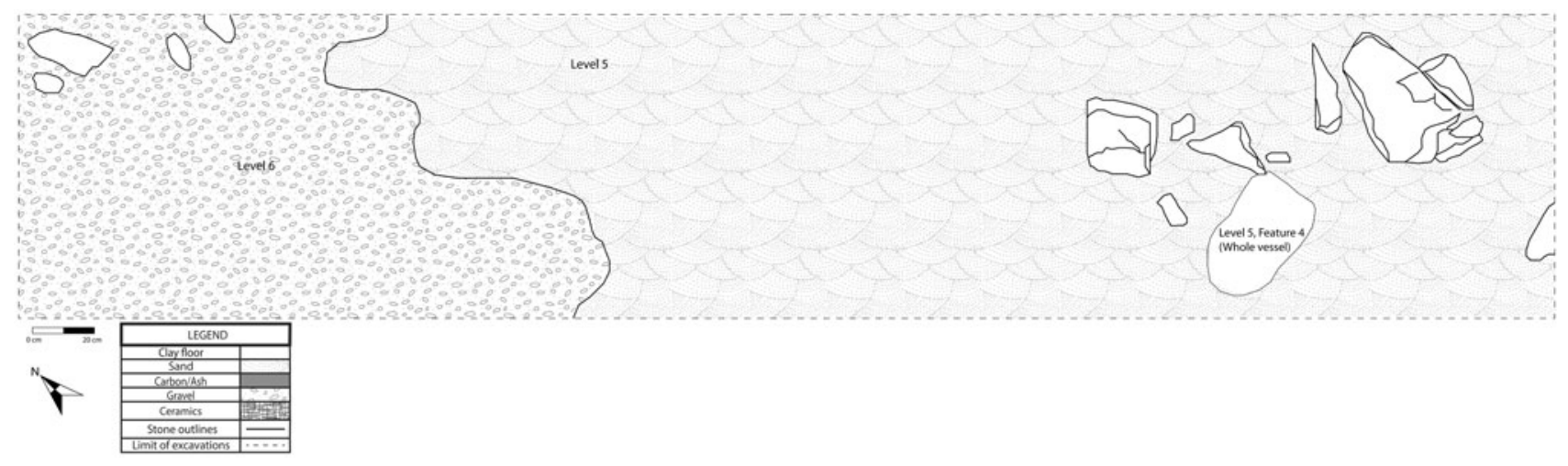

Figure 7. Plan map of Unit 5-2013, Level 5, with whole vessel identified.

operations for household groups residing at this site during the Late Moche period.

\section{Discussion}

Based on these attributes, it is hard to deny the possibility that the vessel and its contents were a dedicatory offering of some sort. This large, whole vessel, placed on its side and buried below a prominent stone along with its contents, was likely deposited as an offering to commemorate the construction of a communal kitchen floor or domestic structure. Although it is common for such jars to be found embedded in floors for storage purposes (e.g. Cutright 2009, 72; Shimada 1994, 216; Swenson et al. 2013, 103-4), the diversity of the contents of this vessel is not typical of stored goods-storage vessels are usually more uniform in their contents. Instead, it was likely at one point used as a cooking vessel for soups or stews, as indicated by its burnt exterior and the materials found within and around it. After it no longer functioned as a cooking pot, it was subsequently buried under the floor with a large stone placed over it, suggesting that the location of the vessel under the floor was still acknowledged after its burial.

Furthermore, these materials are the practices that produced them and they are memorialized through their deposition here. In the case of the contents of this pot, this would necessitate the

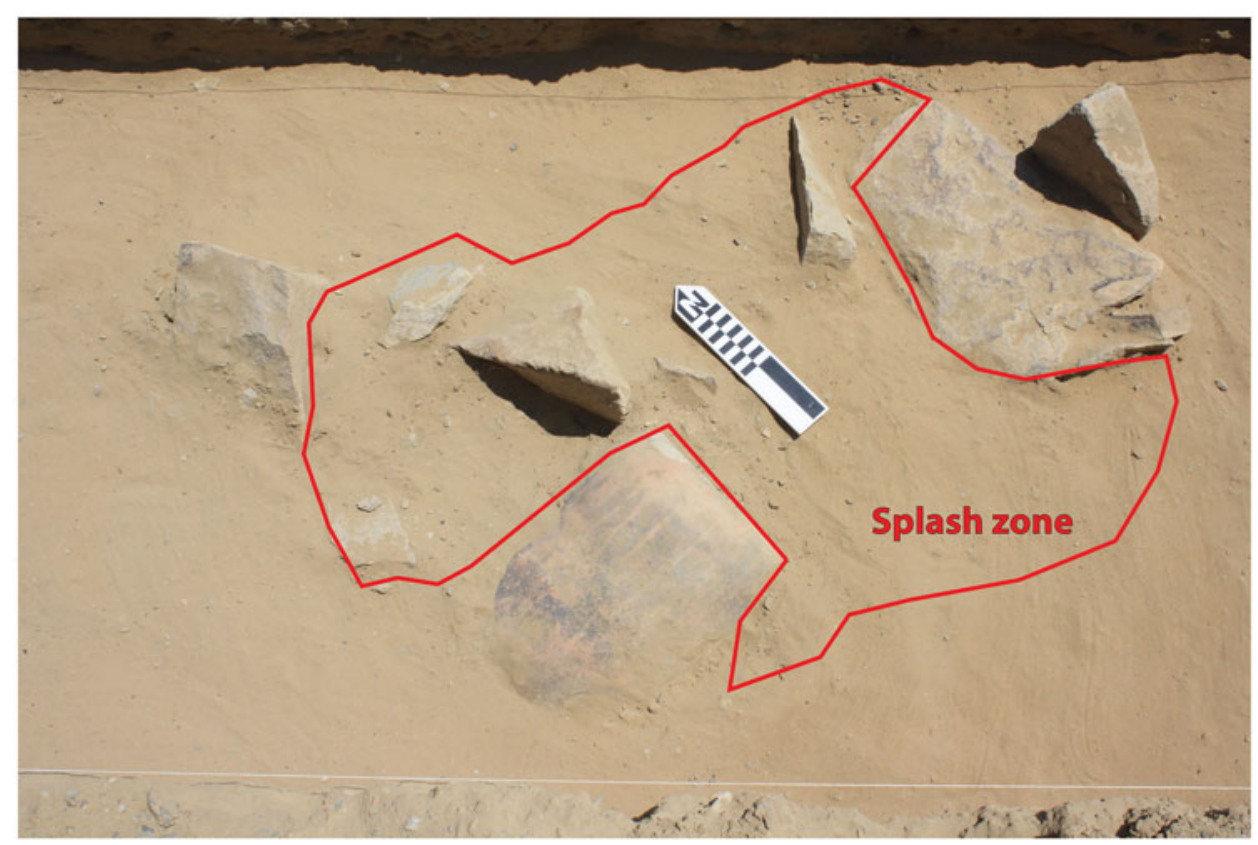

Figure 8. Whole vessel in context with splash zone of materials indicated, from above. 
convergence of practices for preparing, and possibly producing, products from a variety of ecological and geographic regions, each of which requires specific knowledge bases. While the method of cooking was simple-add ingredients plus water to the pot, heat to boil-understanding how and whether to apply particular knowledge was dependent on the material. For example, the means of processing a llama in order to acquire the left maxilla, as found in this pot, requires an entirely different knowledge set than that needed to prepare potatoes or squash, or to butcher a large marine fish. Additionally, obtaining each material required not only different skill sets, but potentially different social networks. For instance, it has been proposed that fishing and farming villages in the Moche period were relatively autonomous from one another (Johnson 2011) and so the acquisition of marine products may have been through trade rather than directly. Also, coca requires very specific environments to grow and almost certainly was obtained via exchange with producers up-valley, or even further away (Cortella et al. 2001; Martin 1970; Rosas R. 2010, 735). It is in the quotidian task of preparing a stew that these multiple knowledge sets are materially assembled and bundled together-the meal could not otherwise be prepared or, ultimately, consumed.

Beyond the specific skill sets for their practical applications in cookery, however, is the knowledge of the social importance of each ingredient. Camelids were extremely important in the Andes for a multitude of reasons, including for wool, their utility as a pack animal and the consumption of their meat, blood, viscera and grease (de Acosta 1590, 293-6; Sandefur 2002; Vallières 2012, 62-3), but their ritual significance was likely as great as their functional significance (Goepfert 2010). Sacrifices and offerings of camelids have been recorded in the Jequetepeque Valley at Pacatnamú (Donnan 1997, 34), San José de Moro (Goepfert 2012, 106), and Huaca Colorada (Swenson et al. 2012) and were an integral element of Moche ritual life. While less ideologically imbued than llamas and alpacas, guinea pigs were still an important part of feasting and ritual events as well as more general, everyday consumption (Arriaga 1968, 210; Miller \& Burger 1995; Sandefur 2002, 182-3; Sandweiss \& Wing 1997).

Maize was clearly of importance to the Moche and was the predominant plant material recovered from most Moche-era archaeological sites (e.g. Gumerman 1997; Shimada 1994, 221-4). It has been recovered from burial contexts (Gumerman 1997) as well as depicted in a wide variety of Moche iconographic representations, including in association with

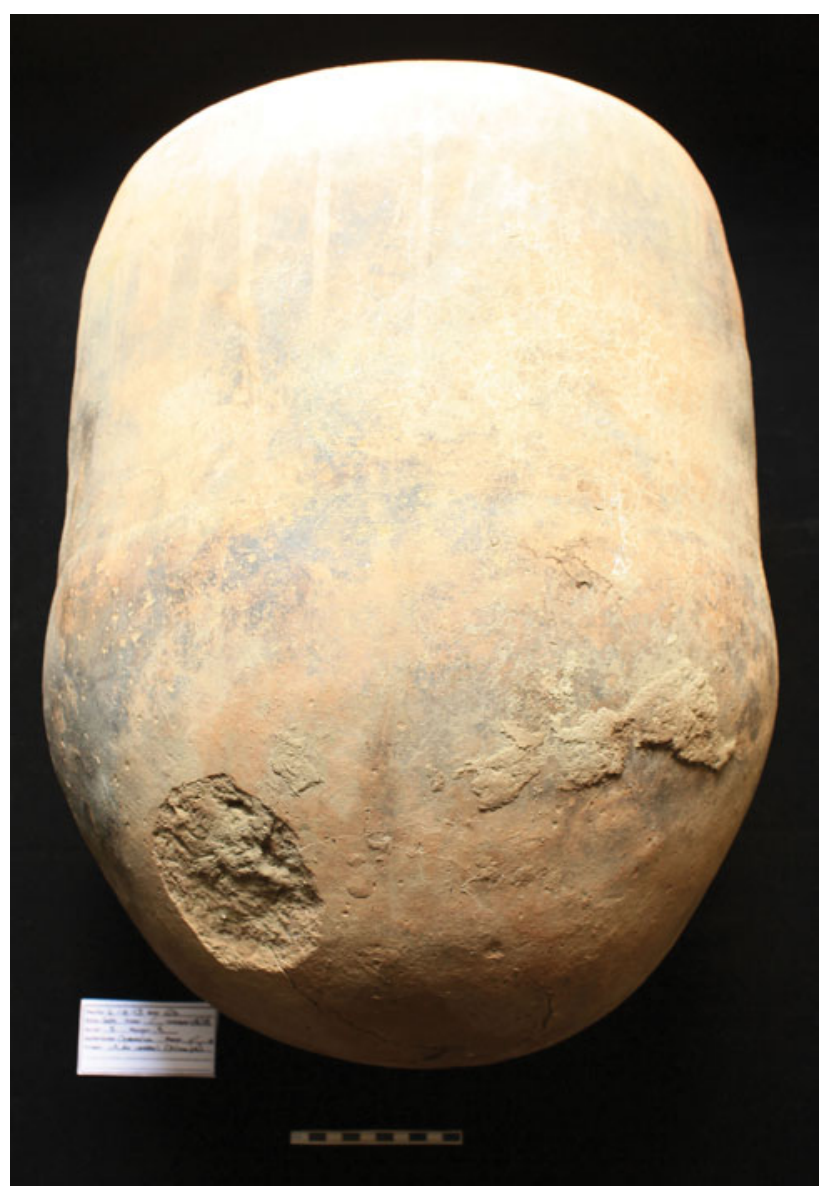

Figure 9. Whole vessel with worn patches and cracks visible.

presentation rituals and as the Moche decapitator deity, Ai Apaec (Donnan 1978; Duke 2017, 64; Eubanks 1999). Maize also held a high status as the main ingredient for making corn beer, or chicha (Burger \& van der Merwe 1990; Weismantel 2009) and may have been an indicator of status during the Moche era (Lockard 2005, 215-19; Ringberg 2012, 260-67).

Common beans had a relatively consistent presence in most domestic and festive contexts across time periods on the coast of Peru and were a crucial part of the Moche diet, though they did not appear to signify status or have any special ritual significance (Gumerman \& Briceño 2003; Pozorski 1979; Rosas R. 2010, 765-9; Ryser 2008). Similarly, squash was one of the most easily grown and wide-ranging cultivars in the Americas, but its social significance appeared to remain within the culinary realm (Cutright 2009; Gumerman 1997). To date, only two examples of potato from the Moche period have been documented: starch grain analyses on dental 
Table 1. Materials recovered from Unit 5-2013, Level 5 and Feature 4 (whole vessel and splash zone).

\begin{tabular}{|c|c|c|c|c|}
\hline Material & Material type & Context & Context type & Description \\
\hline Body sherd & Ceramic & Unit 5, Level 5 & $\begin{array}{l}\text { Splash zone from whole vessel } \\
\text { in sand matrix }\end{array}$ & $\begin{array}{l}12 \text { sherds ( } 10 \text { burnt, all part of } \\
\text { same vessel) }\end{array}$ \\
\hline Body sherd & Ceramic & $\begin{array}{l}\text { Unit 5, Level 5, } \\
\text { Feature } 4\end{array}$ & $\begin{array}{l}\text { Inside large, whole vessel } \\
\text { embedded in sand matrix }\end{array}$ & $\begin{array}{l}1 \text { sherd (burnt, part of burnt } \\
\text { vessel from splash zone) }\end{array}$ \\
\hline Tinaja (whole) & Ceramic & $\begin{array}{l}\text { Unit 5, Level 5, } \\
\text { Feature } 4\end{array}$ & $\begin{array}{l}\text { Whole vessel embedded in } \\
\text { sand matrix }\end{array}$ & $\begin{array}{l}1 \text { large, whole tinaja with } \\
\text { exterior burning, cracks on } \\
\text { bottom and a circular worn } \\
\text { patch near exterior bottom }\end{array}$ \\
\hline Scraping tool & Lithic & Unit 5, Level 5 & $\begin{array}{l}\text { Splash zone from whole vessel } \\
\text { in sand matrix }\end{array}$ & 1 granite scraper \\
\hline Chilli pepper (Capsicum sp.) & $\begin{array}{l}\text { Palaeobotanical } \\
\text { (flotation) }\end{array}$ & Unit 5, Level 5 & $\begin{array}{l}\text { Splash zone from whole vessel } \\
\text { in sand matrix }\end{array}$ & 6 fragments \\
\hline Chilli pepper (Capsicum sp.) & $\begin{array}{l}\text { Palaeobotanical } \\
\text { (flotation) }\end{array}$ & $\begin{array}{l}\text { Unit 5, Level 5, } \\
\text { Feature } 4\end{array}$ & $\begin{array}{l}\text { Inside large, whole vessel } \\
\text { embedded in sand matrix }\end{array}$ & 1 fragment \\
\hline Coca (Erythroxylum coca) & $\begin{array}{l}\text { Palaeobotanical } \\
\text { (flotation) }\end{array}$ & Unit 5, Level 5 & $\begin{array}{l}\text { Splash zone from whole vessel } \\
\text { in sand matrix }\end{array}$ & 2 fragments \\
\hline Coca (Erythroxylum coca) & $\begin{array}{l}\text { Palaeobotanical } \\
\text { (flotation) }\end{array}$ & $\begin{array}{l}\text { Unit 5, Level 5, } \\
\text { Feature } 4\end{array}$ & $\begin{array}{l}\text { Inside large, whole vessel } \\
\text { embedded in sand matrix }\end{array}$ & 2 fragments \\
\hline $\begin{array}{l}\text { Common bean (Phaseolus } \\
\text { vulgaris) }\end{array}$ & $\begin{array}{l}\text { Palaeobotanical } \\
\text { (flotation) }\end{array}$ & $\begin{array}{l}\text { Unit 5, Level 5, } \\
\text { Feature } 4\end{array}$ & $\begin{array}{l}\text { Inside large, whole vessel } \\
\text { embedded in sand matrix }\end{array}$ & 1 fragment \\
\hline Squash (Cucurbita moschata) & $\begin{array}{l}\text { Palaeobotanical } \\
\text { (flotation) }\end{array}$ & $\begin{array}{l}\text { Unit 5, Level 5, } \\
\text { Feature } 4\end{array}$ & $\begin{array}{l}\text { Inside large, whole vessel } \\
\text { embedded in sand matrix }\end{array}$ & 1 fragment \\
\hline Squash (Cucurbita sp.) & $\begin{array}{l}\text { Palaeobotanical } \\
\text { (flotation) }\end{array}$ & Unit 5, Level 5 & $\begin{array}{l}\text { Splash zone from whole vessel } \\
\text { in sand matrix }\end{array}$ & 3 fragments \\
\hline Algarroba (Prosopis sp.) & $\begin{array}{l}\text { Palaeobotanical } \\
\text { (macrobotanical) }\end{array}$ & Unit 5, Level 5 & $\begin{array}{l}\text { Splash zone from whole vessel } \\
\text { in sand matrix }\end{array}$ & 11 seeds \\
\hline Caper bush (Capparis sp.) & $\begin{array}{l}\text { Palaeobotanical } \\
\text { (macrobotanical) }\end{array}$ & $\begin{array}{l}\text { Unit 5, Level 5, } \\
\text { Feature } 4\end{array}$ & $\begin{array}{l}\text { Inside large, whole vessel } \\
\text { embedded in sand matrix }\end{array}$ & 1 bark fragment \\
\hline Maize (Zea mays) & $\begin{array}{l}\text { Palaeobotanical } \\
\text { (macrobotanical) }\end{array}$ & Unit 5, Level 5 & $\begin{array}{l}\text { Splash zone from whole vessel } \\
\text { in sand matrix }\end{array}$ & $1 \mathrm{cob}, 5$ whole kernels \\
\hline Maize (Zea mays) & $\begin{array}{l}\text { Palaeobotanical } \\
\text { (macrobotanical) }\end{array}$ & $\begin{array}{l}\text { Unit 5, Level 5, } \\
\text { Feature } 4\end{array}$ & $\begin{array}{l}\text { Inside large, whole vessel } \\
\text { embedded in sand matrix }\end{array}$ & 1 whole kernel \\
\hline Squash (Cucurbita moschata) & $\begin{array}{l}\text { Palaeobotanical } \\
\text { (macrobotanical) }\end{array}$ & Unit 5, Level 5 & $\begin{array}{l}\text { Splash zone from whole vessel } \\
\text { in sand matrix }\end{array}$ & $\begin{array}{l}2 \text { whole seeds, } 4 \text { seed } \\
\text { fragments }\end{array}$ \\
\hline Squash (Cucurbita moschata) & $\begin{array}{l}\text { Palaeobotanical } \\
\text { (macrobotanical) }\end{array}$ & $\begin{array}{l}\text { Unit 5, Level 5, } \\
\text { Feature } 4\end{array}$ & $\begin{array}{l}\text { Inside large, whole vessel } \\
\text { embedded in sand matrix }\end{array}$ & 1 seed fragment \\
\hline Squash (Cucurbita sp.) & $\begin{array}{l}\text { Palaeobotanical } \\
\text { (macrobotanical) }\end{array}$ & Unit 5, Level 5 & $\begin{array}{l}\text { Splash zone from whole vessel } \\
\text { in sand matrix }\end{array}$ & 4 whole seeds \\
\hline Maize (Zea mays) & $\begin{array}{l}\text { Palaeobotanical } \\
\text { (starch grain) }\end{array}$ & $\begin{array}{l}\text { Unit 5, Level 5, } \\
\text { Feature } 4\end{array}$ & $\begin{array}{l}\text { Inside large, whole vessel } \\
\text { embedded in sand matrix }\end{array}$ & $\begin{array}{l}\text { Scraping from residue inside } \\
\text { large, whole vessel }\end{array}$ \\
\hline Potato (Solanum tuberosum) & $\begin{array}{l}\text { Palaeobotanical } \\
\text { (starch grain) }\end{array}$ & $\begin{array}{l}\text { Unit 5, Level 5, } \\
\text { Feature } 4\end{array}$ & $\begin{array}{l}\text { Inside large, whole vessel } \\
\text { embedded in sand matrix }\end{array}$ & $\begin{array}{l}\text { Scraping from residue inside } \\
\text { large, whole vessel }\end{array}$ \\
\hline Camelid (Lama sp.) & Zooarchaeological & $\begin{array}{l}\text { Unit } 5 \text {, Level 5, } \\
\text { Feature } 4\end{array}$ & $\begin{array}{l}\text { Inside large, whole vessel } \\
\text { embedded in sand matrix }\end{array}$ & $\begin{array}{l}2 \text { bone fragments, including } \\
\text { left maxilla of } 2 \text {-year-old with } \\
\text { premolars } 3 \text { and } 4 \text {, as well as } \\
\text { molars } 1 \text { and } 2\end{array}$ \\
\hline $\begin{array}{l}\text { Flathead mullet (Mugil } \\
\text { cephalus) }\end{array}$ & Zooarchaeological & Unit 5, Level 5 & $\begin{array}{l}\text { Splash zone from whole vessel } \\
\text { in sand matrix }\end{array}$ & 1 bone fragment \\
\hline $\begin{array}{l}\text { Freshwater crab } \\
\text { (Hypolobocera sp.) }\end{array}$ & Zooarchaeological & Unit 5, Level 5 & $\begin{array}{l}\text { Splash zone from whole vessel } \\
\text { in sand matrix }\end{array}$ & 1 fragment \\
\hline $\begin{array}{l}\text { Freshwater crab } \\
\text { (Hypolobocera sp.) }\end{array}$ & Zooarchaeological & $\begin{array}{l}\text { Unit } 5 \text {, Level } 5 \text {, } \\
\text { Feature } 4\end{array}$ & $\begin{array}{l}\text { Inside large, whole vessel } \\
\text { embedded in sand matrix }\end{array}$ & 1 fragment \\
\hline
\end{tabular}


Table 1. Continued

\begin{tabular}{|l|l|l|l|l|}
\hline Material & \multicolumn{1}{|c|}{ Material type } & \multicolumn{1}{|c|}{ Context } & \multicolumn{1}{c|}{ Context type } & \multicolumn{1}{c|}{ Description } \\
\hline Guinea pig (Cavia porcellus) & Zooarchaeological & Unit 5, Level 5 & $\begin{array}{l}\text { Splash zone from whole vessel } \\
\text { in sand matrix }\end{array}$ & 1 bone fragment \\
\hline $\begin{array}{l}\text { Smooth black trochid sea } \\
\text { snail (Tegula atra) }\end{array}$ & Zooarchaeological & Unit 5, Level 5 & $\begin{array}{l}\text { Splash zone from whole vessel } \\
\text { in sand matrix }\end{array}$ & 1 fragment \\
\hline $\begin{array}{l}\text { Smooth black trochid sea } \\
\text { snail (Tegula atra) }\end{array}$ & Zooarchaeological & $\begin{array}{l}\text { Unit 5, Level 5, } \\
\text { Feature 4 }\end{array}$ & $\begin{array}{l}\text { Inside large, whole vessel } \\
\text { embedded in sand matrix }\end{array}$ & 1 fragment \\
\hline
\end{tabular}

calculus from a Moche burial at Huaca Cao Viejo in the Chicama valley (Vásquez et al. 2014) and the starch grain evidence from Wasi Huachuma (Duke 2017, 171; Duke et al. 2018). Despite the lack of macrobotanical evidence for potato, the starch grain evidence from Wasi Huachuma indicates that it was likely a common part of the daily diet, but likely did not have any elevated status attached to it on the coast (Duke et al. 2018).

Due to their ritual significance and intense flavour, chili peppers have been considered by some to be a restricted luxury food (e.g. Hayden 1990; 1992; 1995). However, chili peppers are not exclusively found within elite or ritual contexts (Chiou et al. 2014; Duke 2017, 427) and the relative ease with which they are grown and stored may indicate that they were more broadly used as a general flavouring than has been previously identified. In many ways, coca shares a similar place in Andean botanical history to chili peppers. Both are relatively easily grown, fairly ubiquitous in the archaeobotanical record, demonstrably associated with ritual, yet also a part of everyday life (Chiou et al. 2014; Cortella et al. 2001; Martin 1970).

The seedpods of algarroba trees were frequently used as camelid fodder and have also been documented in culinary contexts (Johnson 2011, 259). The beans and pods are sometimes fermented to make a specific type of chicha (chicha de algarrobo) or boiled and reduced to create algarrobina, a sweet syrup (Goldstein 2008). The importance of this tree to the Moche was high and it was also frequently depicted on ceramic vessels (Duke 2017, 80), though there does not appear to be any specific ritual or other social importance associated with it. The bark fragments from caper bushes (Capparis sp.) may have been used as a construction material or as fuel for cooking (Fernández H. \& Rodríguez R. 2007, 58-9; Grandtner \& Chevrette 2014, 151; Pozorski 1979; Quilter et al. 1991) but do not appear to have had greater social significance.

Beyond subsistence, fish remains have been recorded as burial offerings (Benson 2012, 110) and depicted in iconography on Moche ceramics (Bawden 2005, 296-8; Benson 2012, 112). In regards to marine gastropods such as Tegula atra, Roselló et al. $(2001,78)$ argue that they 'probably constitute by-products of transport activities or alternative gatherings (i.e. algae, mussels, etc.)', essentially relegating marine gastropods to 'carcasses' rather than as dietary elements, despite their edibility. Marine crab is remarkably ubiquitous in the archaeological record on the Peruvian coast, speaking to its importance as a secondary element in coastal cuisine (Cutright 2009, 177-9; Rosas R. 2010, 749-53). Additionally, they were regularly depicted with other marine animals in iconographic fishing scenes by the Moche (Duke 2017, 60) as well as depicted as or with Ai Apaec (Bourget 1994, 433-6). However, while marine crab was found elsewhere at Wasi Huachuma (Vásquez \& Rosales 2014), the crab recovered from this deposit was a freshwater genus (Hypolobocera). These are far less ubiquitous, though by no means uncommon, either, and were likely procured from the rivers, lakes and irrigation canals in the region.

The ceramics and lithics together indicate an active, lived-in structure in which food was prepared and cooked and pots were used, broken and discarded. The whole vessel itself was clearly well worn and perhaps past its usefulness as a functioning kitchen vessel, potentially indicating that its inclusion here marked a shift from old to new. The appearance of these materials in connection to this specific deposit perhaps indicates more than this, however. These items, like the food stuffs in this assemblage, were intentionally included. The significance of these common food-related materials is important as a bundled collection of edibles and culinary utensils endemic to everyday household life.

Based on the above descriptions, the materials assembled in this dedicatory deposit neatly bundle together the various geographic and environmental regions accessed by the Moche. And while these convergent practicalities were important in the everyday life of the Moche residents of Wasi Huachuma, 
equally important was the deposit of quotidian materials in a likely dedicatory context. They were bundled together precisely as an amalgam of products with a variety of social significances, from the practical to the supernatural, but all of which were a part of the everyday lived experience of a Moche person.

Two similar domestic structures were excavated in the same portion of Wasi Huachuma with similar artifactual and organic remains recovered from both. However, evidence of a dedicatory deposit was only found under the floor of one of them. This may have been due to a number of reasons, including the fact that neither structure was excavated in its entirety, so a similar deposit under the other floor may simply have been missed. It is also possible that the structure from Unit 5-2013 where the deposit was recovered was in some way special or deserving of such a commemoration. The full significance this deposit, as well as any discussion of a potential pattern of dedicatory deposits under the floors of domestic structures at Wasi Huachuma, would require further excavation. However, it is fair to say that this one deposit is indicative that this structure was important to the people constructing it and that they felt that the most appropriate way to mark this importance was through a deposit of a meal beneath its floor.

Ultimately, the most important element of this was that these specific materials were bundled together intentionally (sensu Pauketat 2013). While the intentions themselves may never be knowable, the acts of bundling, depositing and constructing, as well as the materials themselves, all straddle the worlds of the mundane and the special. These doings (sensu Fowles 2013) were neither unambiguously ritual nor quotidian. They were simultaneously both and served as a reminder of the inseparability of these two domains.

\section{Conclusion}

Perhaps this deposit was a meal offered to the gods, or the ancestors, or even the living structure under whose floor it was buried. However, what its exact purpose was I cannot say with any absolute certainty. To paraphrase and apply Igor Kopytoff (2013), the life-history of the pot and its contents are not fully known. The maker of either, whether it was the same person or two (or more) people, is beyond our purview. But it is clear that this deposit, in this location, was purposeful, intentional and laden with meaning. Each element of it was chosen from an array of materials available, some from the local fields and seas, some from much further afield, though not necessarily any less familiar.

Within this pot, beneath this floor, at one point simmered a stew in which geography and time converged; and this convergence was subsequently and purposefully placed here, to be either remembered or forgotten (Mills 2008), the stone marking its placement. Further convergences are also clear. Importantly, this was a utilitarian, everyday pot containing utilitarian, everyday foods. These foods were combined with less utilitarian items, but in a standard, everyday cooking style. But then the whole of these local and foreign foods cooked in this ubiquitous pot was used in a decidedly ritual manner, as a dedicatory deposit during the construction of a domestic structure, effectively blurring the imaginary lines between ritual/quotidian, domestic/supernatural.

The convergences of these foods, these practices, at this obscure site highlight the intricate interconnectedness of the surrounding area and the regions beyond. Additionally, these convergences extend beyond geography and ecology, beyond time periods, and into the realms of cosmology and embodied cultural practice. This stew, in this pot, under this floor, at this site encompassed the convergences of practices, the convergences of geography and ecology, the convergences of ideas in a deceptively simple and elegant way that belies its complex entanglements. The entangled convergences of food, ritual, cooking style and daily activities show us how the quotidian, utilitarian world of the Moche feeds special events in both literal and figurative ways. Ultimately, this singular deposit encapsulates the role of the everyday in the special and, perhaps even more importantly, the special in the everyday.

\section{Notes}

1. Donnan \& McClelland $(1997,34)$ point out that llama bones are only present in the burials of some adults, and that these were non-meat-bearing elements such as the skull, lower legs, feet, teeth and scapulae.

2. Gumerman (1991, 10; 1994, 402; 1997, 246) repeatedly mentions the analysis of the Moche middens at Pacatnamú, but does not provide any detailed data or citations. The only information I was able to acquire about the Moche middens is that the presence of marine resources was greater than that of terrestrial agricultural resources. No mention of terrestrial fauna (e.g. camelids, dogs, guinea pig, birds, etc.) was given.

\section{Acknowledgements}

I would first like to thank my excavation team at Wasi Huachuma, Elvis Chávez and André Kinsiño Vidal 
Urquiaga, as well as Elizabeth de la Rosa in Pacasmayo for making the field season that led to this data possible. Additionally, many thanks go out to Ryan Kennedy and Guido Pezzarossi for inviting me to present an early version of this paper at the Theoretical Archaeology Group meetings in Urbana-Champaign in 2014. And lastly, my deep appreciation goes out to Anna Guengerich, Danielle MacDonald, Edward Swenson, Sarah Rowe and the two anonymous reviewers for their commentary and critiques on earlier drafts of this paper.

$$
\begin{array}{r}
\text { Guy S. Duke } \\
\text { University of Texas Rio Grande Valley } \\
\text { Department of Sociology E Anthropology } \\
1201 \text { West University Drive } \\
\text { Edinburg, TX } 78539 \\
\text { USA } \\
\text { Email: guy.duke@utrgv.edu }
\end{array}
$$

\section{References}

Alberti, B. \& T.L. Bray, 2009. Animating archaeology: of subjects, objects and alternative ontologies. Cambridge Archaeological Journal 19(3), 337-43.

Alberti, B. \& Y. Marshall, 2009. Animating archaeology: local theories and conceptually open-ended methodologies. Cambridge Archaeological Journal 19(3), 344-56.

Alberti, B., S. Fowles, M. Holbraad, Y. Marshall \& C. Witmore, 2011. 'Worlds otherwise': archaeology, anthropology, and ontological difference. Current Anthropology 52(6), 896-912.

Arnold, D.Y. (1992). La casa de adobes y piedras del Inka: genero, memoria y cosmos en Qaqachaka [The Inka house of adobe and stone: gender, memory, and cosmology in Qaqachaka], in Hacia un orden andino de las cosas [Towards an Andean order of things], ed. D. Y. Arnold. La Paz: HISBOL, 31-108.

Arriaga, P.J., 1968. Extirpación de idolatría del Pirú [Extirpation of idolatry in Peru], in Crónicas peruanas de interés indígena [Peruvian chronicles of indigenous interest], ed. F. Esteve Barba. Madrid: Ediciones Atlas, 191-276.

Arsenault, D., 1992. Ritual dietary practices in Mochica society: the context of the feast. Recherches amérindiennes au Québec 22(1), 45-64.

Bawden, G., 1996. The Moche. Oxford: Blackwell.

Bawden, G., 2005. Ethnogenesis at Galindo, Peru, in Us and Them: Archaeology and ethnicity in the Andes, ed. R. M. Reycraft. Los Angeles (CA): Cotsen Institute of Archaeology, UCLA, 12-33.

Benson, E.P., 2012. The Worlds of the Moche on the North Coast of Peru. Austin (TX): University of Texas Press.

Bourdieu, P., 1979. The Kabyle house of the world reversed, in Algeria 1960, by P. Bourdieu (trans. R. Nice). Cambridge: Cambridge University Press, 133-53.

Bourget, S., 1994. Los sacerdotes a la sombra del Cerro Blanco y del Arco Bicéfalo [The priests in the shadow of Cerro Blanco and Arco Bicéfalo]. Revista del Museo de Arqueología, Antropología e Historía 5, 81-125.

Bray, T.L., 2003. Inka pottery as culinary equipment: food, feasting, and gender in imperial state design. Latin American Antiquity 14(1), 3-38.

Bray, T.L., 2009. An archaeological perspective on the Andean concept of camaquen: thinking through late Pre-Columbian ofrendas and huacas. Cambridge Archaeological Journal 19(3), 357-366.

Brück, J., 1999. Ritual and rationality: some problems of interpretation in European archaeology. European Journal of Archaeology 2(3), 313-44.

Burger, R.L. \& N.J. van der Merwe, 1990. Maize and the origin of highland Chavín civilization: an isotopic perspective. American Anthropologist 92(1), 85-95.

Bussmann, R. W. \& D. Sharon, 2009. Naming a phantom the quest to find the identity of Ulluchu, an unidentified ceremonial plant of the Moche culture in northern Peru. Journal of Ethnobiology and Ethnomedicine 5(8). http://doi.org/10.1186/ 1746-4269-5-8

Castillo, L.J., 2001. The last of the Mochicas: a view from the Jequetepeque Valley, in Moche Art and Archaeology in Ancient Peru, ed. J. Pillsbury. Washington (DC): National Gallery of Art, 307-32.

Castillo, L.J., 2010. Moche politics in the Jequetepeque Valley: a case for political opportunism, in New Perspectives on Moche Political Organization, eds. J. Quilter \& L.J. Castillo B. Washington (DC): Dumbarton Oaks, 83-109.

Castillo, L.J., 2012. San José de Moro y el fin de los Mochicas en el valle de Jequetepeque, costa norte del Peru [San José de Moro and the last of the Mochica in the Jequetepeque valley, north coast of Peru]. Unpublished PhD thesis, University of California, Los Angeles.

Chicoine, D., 2011. Feasting landscapes and political economy at the Early Horizon center of Huambacho, Nepeña Valley, Peru. Journal of Anthropological Archaeology 30(3), 432-53.

Chiou, K.L. 2017. Common Meals, Noble Feasts: An Archaeological Investigation of Moche Food and Cuisine in the Jequetepeque Valley, Peru, AD 600800. Unpublished PhD thesis, University of California, Berkeley.

Chiou, K.L., C.A. Hastorf, D. Bonavia \& T.D. Dillehay, 2014. Documenting cultural selection pressure changes on chile pepper (Capsicum baccatum L.) seed size through time in coastal Peru (7,600 B.P.present). Economic Botany 68(2), 190-202.

Cortella, A.R., M.L. Pochettino, A. Manzo \& G. Raviña, 2001. Erythroxylum coca: microscopical identification in powdered and carbonized archaeological material. Journal of Archaeological Science 28, 787-94.

Costin, C.L. \& T. Earle, 1989. Status distinction and legitimation of power as reflected in changing patterns of consumption in late prehispanic Peru. American Antiquity 54(4), 691-714. 
Cummins, T., 2002. Toasts With The Inca: Andean abstraction and colonial images on quero vessels. Ann Arbor (MI): University of Michigan Press.

Cusicanqui M., S., 2010. Investigaciones arqueológicas en los asentamientos de San Ildefonso y Cerro Chepén, valle bajo de Jequetepeque [Archaeological investigations in the settlements of San Ildefonso and Cerro Chepén, lower Jequetepeque valley]. Unpublished MA thesis, Pontificia Universidad Católica del Perú.

Cutright, R.E., 2009. Between the Kitchen and the State: Domestic Practice and Chimú Expansion in the Jequetepeque Valley, Peru. Unpublished Ph.D thesis, University of Pittsburgh.

Cutright, R.E., 2011. Food for the dead, cuisine for the living: mortuary food offerings from the Jequetepeque Valley, Peru, in From State to Empire in the Prehistoric Jequetepeque Valley, Peru, eds. I. Johnson \& C.M. Zori. Oxford: Archaeopress, 83-92.

de Acosta, J., 1590. Historia natural y moral de las Indias [Natural and moral history of the Indies]. Seville: Juan de Léon.

de Rios, M.D., 1977. Plant hallucinogens and the religion of the Mochica: an ancient Peruvian People. Economic Botany 31(2), 189-203.

DeLanda, M., 2006. A New Philosophy of Society: Assemblage theory and social complexity. New York (NY): Continuum.

Deleuze, G. \& F. Guattari, 1993. A Thousand Plateaus (2nd edn). Minneapolis (MN): University of Minnesota Press.

Delibes, R. \& A. Barragán, 2008. Consumo ritual de chicha en San José de Moro [Ritual consumption of chicha in San José de Moro], in Arqueología Mochica: Nuevas Enfoques: Actas del primero congreso internacional de jóvenes investigadores de la cultura Moche [Moche Archaeology: New Approaches: Proceedings of the First International Congress of Young Researchers of the Moche Culture], eds. L.J. Castillo, H. Bernier, G. Lockard \& J. Rucabado Y. Lima: Pontificia Universidad Católica del Perú, 105-18.

Dietler, M., 2001. Rituals of consumption, commensal politics, and power in African contexts, in Feasts: Archaeological and ethnographic perspectives on food, politics, and power, eds. M. Dietler \& B. Hayden. Washington (DC): Smithsonian Institution Press, 65-114.

Dillehay, T.D., 2001. Town and country in Late Moche times: a view from two northern valleys, in Moche Art and Archaeology in Ancient Peru, ed. J. Pillsbury. Washington (DC): National Gallery of Art, 259-84.

Dillehay, T.D. \& A.L. Kolata, 2004. Long-term human response to uncertain environmental conditions in the Andes. Proceedings of the National Academy of Sciences 101(12), 4325-30.

Dillehay, T.D., A.L. Kolata \& E.R. Swenson, 2009. Paisajes culturales en el valle del Jequetepeque: Los yacimientos arqueológicos [Cultural landscapes in the Jequetepeque valley: The archaeological sites]. Trujillo: Ediciones SIAN.
Dillehay, T.D., A.L. Kolata \& M. Pino Q., 2004. Pre-industrial human and environment interactions in northern Peru during the late Holocene. The Holocene 14(2), 272-81.

Donnan, C.B., 1978. Moche Art of Peru. Los Angeles (CA): Museum of Cultural History, UCLA.

Donnan, C.B., 1992. Ceramics of Ancient Peru. Los Angeles (CA): Fowler Museum of Cultural History, UCLA.

Donnan, C.B., 1997. A Chimu-Inka ceramic-manufacturing center from the north coast of Peru. Latin American Antiquity 8(1), 30-54.

Donnan, C.B., 2006. A Moche cemetery at Masanca, Jequetepeque Valley, Peru. Nawpa Pacha: Journal of Andean Archaeology 28, 151-93.

Donnan, C.B., 2007. Moche tombs at Dos Cabezas. Los Angeles (CA): Cotsen Institute of Archaeology, UCLA.

Donnan, C.B. \& G.A. Cock (eds.), 1997. The Pacatnamu Papers: Volume 2, The Moche occupation. Los Angeles (CA): Fowler Museum of Cultural History, UCLA.

Donnan, C.B. \& D. McClelland, 1979. The Burial Theme in Moche Iconography. Washington (DC): Dumbarton Oaks.

Donnan, C.B. \& D. McClelland, 1997. Moche burials at Pacatnamu, in The Pacatnamu Papers: Volume 2, The Moche occupation, eds. C.B. Donnan \& G.A. Cock. Los Angeles (CA): Fowler Museum of Cultural History, UCLA, 17-187.

Duke, G.S., 2017. Consuming Identities: Communities and Culinary Practice in the Late Moche Jequetepeque Valley, Peru. Unpublished PhD thesis, University of Toronto.

Duke, G.S., V.F. Vásquez-Sanchez \& T.E. Rosales-Tham, 2018. Starch grain evidence of potato at the Late Moche (AD 600-850) site of Wasi Huachuma, Peru. Journal of Archaeological Science 100C, 74-9.

Eubanks, M., 1999. Corn in Clay: Maize paleoethnobotany in pre-Columbian art. Gainesville (FL): University Press of Florida.

Fernández H., A.M. \& E.F. Rodríguez R., 2007. Etnobotánico del Perú pre-Hispano [Ethnobotany of pre-Hispanic Peru]. Trujillo: Ediciones Herbarium Truxillense (HUT), Universidad Nacional de Trujillo.

Fowles, S., 2013. An Archaeology of Doings: Secularism and the study of Pueblo religion. Santa Fe (NM): School for Advanced Research Press.

Gagnon, C., 2004. Food and the state: bioarchaeological investigations of diet in the Moche Valley of Perú. Dental Anthropology 17(2), 45-54.

Glowacki, M., 2005. Food of the gods or mere mortals? Hallucinogenic Spondylus and its interpretive implications for early Andean society. Antiquity 79, 257-68.

Goepfert, N., 2010. The llama and the deer: dietary and symbolic dualism in the central Andes. Anthropozoologica 45(1), 25-45.

Goepfert, N., 2012. New zooarchaeological and funerary perspectives on Mochica culture (a.d. 100-800), Peru. Journal of Field Archaeology 37(2), 104-20. 
Goldstein, R.C., 2008. Hearths, grinding stones, and households: rethinking domestic economy in the Andes. Archaeological Papers of the American Anthropological Association 18(1), 37-48.

Gose, P., 1991. House rethatching in an Andean annual cycle: practice, meaning, and contradiction. American Ethnologist 18, 39-66.

Graff, S.R. \& E. Rodríguez-Alegría (eds.), 2012. The Menial Art of Cooking. Archaeological studies of cooking and food preparation. Boulder (CO): University of Press of Colorado.

Grandtner, M.M. \& J. Chevrette (eds.), 2014. Dictionary of Trees, Volume 2: South America. London: Academic Press.

Gumerman, G.J. IV, 1991. Subsistence and Complex Societies: Diet between Diverse Socio-economic Groups at Pacatnamu, Peru. Unpublished PhD thesis, University of California, Los Angeles.

Gumerman, G.J. IV, 1994. Corn for the dead: the significance of Zea mays in Moche burial offerings, in Corn and Culture in the Prehistoric New World, eds. S. J. Johannessen \& C.A. Hastorf. Boulder (CO): Westview Press, 399-410.

Gumerman, G.J. IV, 1997. Botanical offerings in Moche burials at Pacatnamu, in The Pacatnamu Papers: Volume 2, The Moche Occupation, eds. C.B. Donnan \& G. A. Cock. Los Angeles (CA): Fowler Museum of Cultural History, UCLA, 243-9.

Gumerman, G.J. IV, 2010. Big hearths and big pots: Moche feasting on the north coast of Peru, in Inside Ancient Kitchens: New directions in the study of daily meals and feasts, ed. E.A. Klarich. Boulder (CO): University Press of Colorado, 111-31.

Gumerman, G.J. IV \& J. Briceño R., 2003. Santa RosaQuirihuac y Ciudad de Dios: Asentamientos rurales en la parte media del valle de Moche [Santa RosaQuirihuac and Ciudad de Dios: rural settlements in the middle Moche valley], in Moche hacia el final del milenio [Moche towards the end of the millennium], eds. S. Uceda \& E. Mujica. Trujillo: Universidad Nacional de Trujillo, 217-44.

Hastorf, C.A., 1991. Gender, space, and food in prehistory, in Engendering Archaeology, eds. J.M. Gero \& M. W. Conkey. Oxford: Oxford University Press, 132-59.

Hastorf, C.A., 2003. Andean luxury foods: special food for the ancestors, deities and the élite. Antiquity 77, 545-54.

Hayashida, F.M., 2008. Ancient beer and modern brewers: ethnoarchaeological observations of chicha production in two regions of the North Coast of Peru. Journal of Anthropological Archaeology 27(2), 161-74.

Hayden, B., 1990. Nimrods, piscators, pluckers, and planters: the emergence of food production. Journal of Anthropological Archaeology 9, 31-69.

Hayden, B., 1992. Models of domestication, in Transitions to Agriculture in Prehistory, eds. A.B. Gebauer \& T. D. Price. Madison (WI): Prehistory Press, 11-19.

Hayden, B., 1995. A new overview of domestication, in Last Hunters, First Farmers: New perspectives on the prehistoric transition to agriculture, eds. T.D. Price \& A.
B. Gebauer. Santa Fe (NM): School of American Research, 273-99.

Isbell, W.H. \& A. Groleau, 2010. The Wari Brewer Woman: feasting, gender, offerings, and memory, in Inside Ancient Kitchens: New directions in the study of daily meals and feasts, ed. E.A. Klarich. Boulder (CO): University Press of Colorado, 191-219.

Jennings, J. \& B.J. Bowser (eds.), 2009. Drink, Power, and Society in the Andes. Gainesville (FL): University Press of Florida.

Jennings, J. \& G.S. Duke, 2018. Making the typical exceptional: the elevation of Inca cuisine, in The Oxford Handbook of the Inca, eds. S.S. Alconini \& R. A. Covey. Oxford: Oxford University Press, 303-21.

Johnson, I., 2010. Households and Social Organization at the Late Moche Period Site of Pampa Grande, Peru. Unpublished PhD thesis, University of California, Los Angeles.

Johnson, I., 2011. The development of semi-autonomous communities in the Late Moche Period (AD 600900), in From State to Empire in the Prehistoric Jequetepeque Valley, Peru, eds. C.M. Zori \& I. Johnson. Oxford: Archaeopress, 51-64.

Johnson, I. \& C.M. Zori, 2011. Introduction: state and empire in the Jequetepeque Valley, in From State to Empire in the Prehistoric Jequetepeque Valley, Peru, eds. C.M. Zori \& I. Johnson. Oxford: Archaeopress, $1-32$.

Kellner, C. \& M. Schoeninger, 2007. A simple carbon isotope model for reconstructing prehistoric human diet. American Journal of Physical Anthropology 133 (4), 1112-27.

Kertzer, D.I., 1988. Ritual, Politics, and Power. New Haven (CT): Yale University Press.

Klarich, E.A. (ed.), 2010. Inside Ancient Kitchens: New directions in the study of daily meals and feasts. Boulder (CO): University Press of Colorado.

Knudson, K.J., K.R. Gardella \& J. Yaeger, 2012. Provisioning Inka feasts at Tiwanaku, Bolivia: the geographic origins of camelids in the Pumapunku complex. Journal of Archaeological Science 39(2), 479-91.

Kopytoff, I., 2013. The cultural biography of things: commoditization as process, in The Social Life of Things: Commodities in cultural perspective, ed. A. Appadurai. Cambridge: Cambridge University Press, 64-91.

Kurin, D.S., 2015. Trauma, nutrition, and malnutrition in the Andean highlands during Peru's Dark Age (1000-1250 C.E.), in The Archaeology of Food and Warfare, eds. A.M. VanDerwarker \& G.D. Wilson. New York (NY): Springer International Publishing, 229-57.

Lau, G.F., 2002. Feasting and ancestor veneration at Chinchawas, north highlands of Ancash, Peru. Latin American Antiquity 13(3), 279-304.

Lockard, G.D., 2005. Political Power and Economy at the Archaeological Site Galindo, Moche Valley, Peru. Unpublished PhD thesis, University of New Mexico. 
Logan, A.L., 2012. A History of Food Without History. Unpublished PhDthesis, University of Michigan, Ann Arbor.

Logan, A.L., C.A. Hastorf \& D.M. Pearsall, 2012. 'Let's drink together': early ceremonial use of maize in the Titicaca Basin. Latin American Antiquity 23(3), 235-58.

Martin, R.T., 1970. The role of coca in the history, religion, and medicine of South American Indians. Economic Botany 24(4), 422-38.

Mauss, M., 1973. Techniques of the body. Economy and Society 2(1), 70-88.

Mayer, E., 1977. Beyond the nuclear family, in Andean Kinship and Marriage, eds. R. Bolton \& E. Mayer. (AAA Special Publication 7.) Washington (DC): American Anthropological Association, 60-80.

Miller, G. \& R.L. Burger, 1995. Our father the cayman, our dinner the llama: animal utilization at Chavin de Huantar, Peru. American Antiquity 60(3), 421-58.

Mills, B.J., 2008. Remembering while forgetting: depositional practices and social memory at Chaco, in Memory Work, eds. B.J. Mills \& W.H. Walker. Santa Fe (NM): School for Advanced Research Press, 81-108.

Morris, C., 1979. Maize beer in the economy, politics, and religion of the Inca Empire, in Fermented Food Beverages in Nutrition, eds. C.F. Gastineau, W.J. Darby \& T.B. Turner. New York (NY): Academic Press, 21-34.

Moseley, M.E., C.B. Donnan \& D.K. Keefer, 2008. Convergent catastrophe and the demise of Dos Cabezas, in The Art and Archaeology of the Moche: An ancient Andean society of the Peruvian north coast, eds. S. Bourget \& K.L. Jones. Austin (TX): University of Texas Press, 81-91.

Moore, J.D., 2018. Andean statecraft before the Incas, in The Oxford Handbook of the Inca, eds. S.S. Alconini \& R. A. Covey. Oxford: Oxford University Press, 31-54.

Narváez V., A., 1994. La Mina: una tumba Moche I en el valle de Jequetepeque [La Mina: a Moche I tomb in the Jequetepeque valley], in Moche: propuestas y perspectivas: Actas del Primer Coloquio sobre la Cultura Moche, Trujillo, 12 al 16 de abril de 1993 [Moche: Proposals and Perspectives: Proceedings of the First Colloquium on the Moche Culture, Trujillo, April 12-16, 1993], ed. S. Uceda \& E. Mujica. Lima: Travaux de l'IFEA, 59-92.

Nash, D.J., 2010. Fine dining and fabulous atmosphere: feasting facilities and political interaction in the Wari realm, in Inside Ancient Kitchens: New directions in the study of daily meals and feasts, ed. E.A. Klarich. Boulder (CO): University Press of Colorado, 81-109.

Pauketat, T.R., 2013. An Archaeology of the Cosmos: Rethinking agency and religion in ancient America. New York (NY): Routledge.

Pozorski, S.G., 1979. Prehistoric diet and subsistence of the Moche valley, Peru. World Archaeology 11(2), 163-84.

Pozorski, S.G. \& T.G. Pozorski, 1979. An early subsistence exchange system in the Moche valley, Peru. Journal of Field Archaeology 6(4), 413-32.
Quilter, J. \& M.L. Koons, 2012. The fall of the Moche: a critique of claims for South America's first state. Latin American Antiquity 23(2), 127-43.

Quilter, J., B. Ojeda E, D.M. Pearsall, D.H. Sandweiss, J. G. Jones \& E.S. Wing, 1991. Subsistence economy of El Paraiso, an early Peruvian site. Science 251(4991), 277-83.

Quilter, J. \& T. Stocker, 1983. Subsistence economies and the origins of Andean complex societies. American Anthropologist 85(3), 545-62.

Ringberg, J.E., 2012. Daily Life at Cerro Leon, an Early Intermediate Period Highland Settlement in the Moche Valley, Peru. Unpublished PhD thesis, University of North Carolina, Chapel Hill.

Rosas R., M., 2010. Cerro Chepén and the Late Moche Collapse in the Jequetepeque Valley, North Coast of Peru. Unpublished PhD thesis, University of New Mexico.

Roselló, E., V. Vasquez, A. Morales \& T. Rosales, 2001. Marine resources from an urban Moche (470-600 AD) area in the 'Huacas del Sol y de la Luna' archaeological complex (Trujillo, Peru). International Journal of Osteoarchaeology 11, 72-87.

Rowe, J.H., 1946. Inca culture at the time of the Spanish conquest, in Handbook of South American Indians, ed. J.H. Steward. Washington (DC): Bureau of American Ethnology, 183-330.

Ryser, G., 2008. Moche bean warriors and the paleobotanic record: why privilege beans? in Arqueología Mochica: Nuevas Enfoques: Actas del primero congreso internacional de jóvenes investigadores de la cultura Moche [Moche Archaeology: New Approaches: Proceedings of the First International Congress of Young Researchers of the Moche Culture], eds. L.J. Castillo, H. Bernier, G. Lockard \& J. Rucabado Y. Lima: Pontificia Universidad Católica del Perú, 397-409.

Sandefur, E.C., 1988. Andean Zooarchaeology: Animal Use and the Inka Conquest of the Upper Mantaro Valley. Unpublished PhD thesis, University of California, Los Angeles.

Sandefur, E.C., 2002. Animal husbandry and meat consumption, in Empire and Domestic Economy, eds. T. N. D'Altroy \& C.A. Hastorf. Boston (MA): Kluwer, 179-202.

Sandweiss, D.H. \& E.S. Wing, 1997. Ritual rodents: the guinea pigs of Chincha, Peru. Journal of Field Archaeology 24(1), 47-58.

Shimada, I., 1982. Horizontal archipelago and coasthighland interaction in north Peru: archaeological models. Senri Ethnological Studies Osaka 10, 137-210.

Shimada, I., 1994. Pampa Grande and the Mochica Culture. Austin (TX): University of Texas Press.

Shimada, M. \& I. Shimada, 1985. Prehistoric llama breeding and herding on the north coast of Peru. American Antiquity 50(1), 3-26.

Shimada, I., C. Schaaf, L. Thompson \& E. Mosley-Thompson, 1991. Cultural impacts of severe droughts in the prehistoric Andes: application 
of a 1,500-year ice core precipitation record. World Archaeology 22(3), 247-70.

Stahl, P.W., 2008. Animal domestication in South America, in The Handbook of South American Archaeology, eds. H. Silverman \& W.H. Isbell. New York (NY): Springer, 121-30.

Swenson, E.R., 2004. Ritual and Power in the Urban Hinterland: Religious Pluralism and Political Decentralization in Late Moche Jequetepeque, Peru. Unpublished PhD, University of Chicago.

Swenson, E.R., 2006. Competitive feasting, religious pluralism and decentralized power in the Late Moche period, in Andean Archaeology III. North and south, ed. H. Silverman. New York (NY): Springer, 112-42.

Swenson, E.R., 2007. Adaptive strategies or ideological innovations? Interpreting sociopolitical developments in the Jequetepeque Valley of Peru during the Late Moche period. Journal of Anthropological Archaeology 26(2), 253-82.

Swenson, E.R., 2008. San Ildefonso and the 'popularization' of Moche ideology in the Jequetepeque Valley, in Arqueología Mochica: Nuevas Enfoques: Actas del primero congreso internacional de jóvenes investigadores de la cultura Moche [Moche Archaeology: New Approaches: Proceedings of the First International Congress of Young Researchers of the Moche Culture], eds. L.J. Castillo, H. Bernier, G. Lockard \& J. Rucabado Y. Lima: Pontificia Universidad Católica del Perú, 411-31.

Swenson, E.R., 2011. Stagecraft and the politics of spectacle in ancient Peru. Cambridge Archaeological Journal 21(2), 283-313.

Swenson, E.R., 2012. Warfare, gender, and sacrifice in Jequetepeque, Peru. Latin American Antiquity 23(2), 167-93.

Swenson, E., J. Chiguala \& J. Warner, 2012. Proyecto de investigación arqueológica Jatanca-Huaca Colorada, valle de Jequetepeque [Archaeological research project at Jatanca-Huaca Colorada, Jequetepeque valley]. (Technical Report, 2011 Field Season.) Lima: Ministerio de Cultura.

Swenson, E., J. Chiguala \& J. Warner, 2013. Proyecto de investigación arqueológica Jatanca-Huaca Colorada, valle de Jequetepeque [Archaeological research project at Jatanca-Huaca Colorada, Jequetepeque valley]. (Technical Report, 2012 Field Season.) Lima: Ministerio de Cultura.
Swenson, E.R. \& J.P. Warner, 2016. Landscapes of mimesis and convergence in the southern Jequetepeque Valley, Peru. Cambridge Archaeological Journal 26(1), 23-51.

Vallières, C., 2012. A Taste of Tiwanaku: Daily Life in an Ancient Andean Urban Center as Seen through Cuisine. Unpublished PhD, McGill University.

Vásquez, V.F., R.F. Jordán \& T.E. Rosales, 2014. Almidones antiguos del cálculo dental de un entierro mochica de la Huaca Cao Viejo, complejo arqueológico El Brujo, costa norte del Perú [Ancient starch grains from the dental calculus of a Moche burial at Huaca Cao Viejo, El Brujo Archaeological Complex, north coast of Peru]. Revista ARCHAEOBIOS 8(1), 6-16.

Vásquez, V.F. \& T.E. Rosales, 2014. Restos de fauna y vegetales del sitio Je64, valle de Jequetepeque - temporada 2013 [Animal and plant remains from Je-64, Jequetepeque valley - 2013 season], in Consuming Identities: Communities and Culinary Practice in the Late Moche Jequetepeque Valley, Peru, by G.S. Duke. Unpublished PhD thesis, University of Toronto, Appendix A.

Weismantel, M., 1989. Making breakfast and raising babies: Tthe Zumbagua household as constituted process, in The Household Economy: Reconsidering the domestic mode of production, ed. R.R. Wilk. Boulder (CO): Westview Press, 55-72.

Weismantel, M.J., 2009. Have a drink: chicha, performance, and politics, in Drink, Power, and Society in the Andes, eds. J. Jennings \& B.J. Bowser. Gainesville (FL): University Press of Florida, 257-78.

Zori, C.M., 2011. Social roles of cemeteries in the Jequetepeque Valley system, in From State to Empire in the Prehistoric Jequetepeque Valley, Peru, eds. I. Johnson \& C.M. Zori. Oxford: Archaeopress, 33-49.

\section{Author biography}

Guy S. Duke is an Assistant Professor of anthropology and archaeology at the University of Texas Rio Grande Valley. He has been conducting research in South America since 2006 with an emphasis on food production/consumption, identity and social interaction. The information for this article stems from his doctoral research at Wasi Huachuma. Currently, he is working on the coast of Ecuador investigating changes in foodways during the Late Formative period Valdivia culture. 